\title{
Article \\ Edge Microstructure and Strength Gradient in Thermally Cut Ti-Alloyed Martensitic Steels
}

\author{
Andrii G. Kostryzhev ${ }^{1,2, *}$, Muhammad Rizwan ${ }^{1}{ }^{\mathbb{D}}$, Chris R. Killmore ${ }^{3}$, Dake Yu ${ }^{4}$ and Huijun Li ${ }^{2}$ \\ 1 ARC Research Hub for Australian Steel Manufacturing, University of Wollongong, \\ Wollongong, NSW 2522, Australia; mr075@uowmail.edu.au \\ 2 School of Mechanical, Materials, Mechatronic and Biomedical Engineering, University of Wollongong, \\ Wollongong, NSW 2522, Australia; huijun@uow.edu.au \\ 3 BlueScope Steel Limited, Five Islands Rd., Port Kembla, NSW 2505, Australia; \\ chris.killmore@bluescopesteel.com \\ 4 Bisalloy Steels, 18 Resolution Drive, Unanderra, NSW 2526, Australia; dake.yu@bisalloy.com.au \\ * Correspondence: andii@uow.edu.au or kostryzhev@yahoo.com
}

Citation: Kostryzhev, A.G.;

Rizwan, M.; Killmore, C.R.; Yu, D.;

Li, H. Edge Microstructure and Strength Gradient in Thermally Cut Ti-Alloyed Martensitic Steels. Metals 2021, 11, 1138. https://doi.org/ $10.3390 /$ met11071138

Academic Editor: Massimo Pellizzari

Received: 15 June 2021

Accepted: 16 July 2021

Published: 19 July 2021

Publisher's Note: MDPI stays neutral with regard to jurisdictional claims in published maps and institutional affiliations.

Copyright: (c) 2021 by the authors. Licensee MDPI, Basel, Switzerland. This article is an open access article distributed under the terms and conditions of the Creative Commons Attribution (CC BY) license (https:/ / creativecommons.org/licenses/by/ $4.0 /$ )

\begin{abstract}
Recently developed Ti-alloyed martensitic steels are believed to exhibit higher wear resistance than traditionally quenched and tempered medium carbon steels. However, their properties may deteriorate during thermal cutting and welding as a result of microstructure tempering. This would present significant challenges for the metal fabrication industries. A decrease in strength and wear resistance associated with tempering should vary with steel composition, initial steel microstructure and properties, and cutting method. In this work, we investigated the effect of thermal cutting on the edge microstructure and properties in two alloyed plate steels containing 0.27C-0.40Ti and $0.39 \mathrm{C}-0.60 \mathrm{Ti}$ (wt.\%) commercially rolled to $12 \mathrm{~mm}$ thickness. Three cutting methods were applied to each of the two plates: oxy-fuel, plasma and water-jet. Microstructure characterisation was carried out using optical and scanning electron microscopy. With an increase in thermal effect, from water-jet to plasma to oxy-fuel, the heat affected zone width increased and hardness decreased in both steels. However, the hardness profile from the cut edge to the base metal significantly varied with steel composition, particularly $\mathrm{C}$ and Ti contents. The dependence of grain structure and precipitation kinetics on steel composition, and cutting method, were thoroughly investigated and linked to the hardness profile variation. The obtained results will be used to optimise the technological parameters for cutting and welding of Ti-alloyed martensitic steels.
\end{abstract}

Keywords: martensitic steel; carbide precipitation; microstructure characterisation; mechanical properties; thermal cutting

\section{Introduction}

Martensitic steels are produced by quenching and tempering the hot rolled plates. Thus, they are usually designated as quenched and tempered (Q\&T) steels. A combination of chemical composition (containing up to $0.36 \mathrm{C}, 1.55 \mathrm{Mn}, 0.55 \mathrm{Si}, 1.9 \mathrm{Cr}, 1 \mathrm{Ni}, 0.65 \mathrm{Mo}$ wt.\%) and carefully chosen temperature and time of tempering result in a very strong and tough material with 360-600 HB of hardness, 500-1400 MPa of the yield stress (YS) and 600-1640 MPa of ultimate tensile strength (UTS) [1-5]. Due to their superior properties, Q\&T steels are widely used in mining, defence and civil construction. Fabrication of the steel structures and units of heavy machinery is carried out using conventional cutting, bending and fusion arc welding processes. The main problem during fabrication is the formation of an edge microstructure highly susceptible to cold cracking [6-13]. Studies of the continuous cooling behaviour of Q\&T armour steel highlighted that when steel is subjected to welding, the area surrounding the weld pool, known as the heat affected zone (HAZ), undergoes complex thermal cycles which cause microstructural changes in the material [8]. The extent and character of these changes depend on thermal cycles 
experienced and may lead to undesirable effects such as HAZ softening (or hardening) and hydrogen induced cold cracking (HICC). The degree of HAZ softening depends on several variables including chemical composition, temperature profile and kinetics of phase transformation [7].

Analysis of the literature data [14-21] for steels suggests that martensitic microstructures generally show a better abrasion resistance compared to other types of microstructure (ferrite, pearlite, bainite). The wear resistance of martensitic and bainitic steels can be improved by increasing the carbon content [22], in particular, due to the formation of hard carbides in a softer matrix $[17,23,24]$. However, an increase in hardness is usually accompanied by a decrease in toughness, leading to a decrease in wear resistance [25]. Thus, the carbon content should not exceed $0.45 \mathrm{wt}$.\% C. To achieve a required combination of high strength and high toughness in commercially rolled plate steels, microalloying with carbide forming elements (such as $\mathrm{Nb}, \mathrm{V}, \mathrm{Ti}, \mathrm{Cr}, \mathrm{Mo}, \mathrm{W}$ ) can be used. High temperature precipitation and solute atoms retard the austenite grain growth (by pinning the grain boundaries) and help to refine the room temperature microstructure. Low temperature precipitation provides particle strengthening and may enhance the dislocation structure development. A combination of strengthening mechanisms operating in steel at room temperature results in simultaneous high strength and toughness. Due to the high prices of microalloying elements, cheaper Ti-alloyed steels were seen as advantageous [26-28].

This article is dedicated to the experimental evaluation of the thermal cutting effect on microstructure and hardness of Ti-alloyed wear resistant steels containing Ti-rich precipitates in a wide range of sizes. As the particle size distributions, grain structure and dislocation structure are expected to vary with heating, thermal cutting should affect the mechanical properties at the cut edge. A probable strength decrease in the HAZ is detrimental for the practical attributes of the studied steels, and, therefore, should be taken into account during edge preparation and welding. In this paper, three common cutting methods were investigated: oxy-fuel, plasma, and water-jet. As the precipitate size distributions and their response to an increasing temperature vary with steel composition, two steel chemistries, with higher and lower Ti and C contents, were studied.

\section{Materials and Experimental Techniques}

Two Ti-alloyed wear resistant plate steels commercially rolled to $12 \mathrm{~mm}$ thickness were studied in this work (Table 1). The steel containing relatively lower contents of carbon and titanium, namely $0.27 \mathrm{wt} . \% \mathrm{C}$ and $0.40 \mathrm{wt} . \%$ Ti was designated as Steel L. Alternatively, the steel with higher carbon and titanium concentrations, $0.39 \mathrm{wt} . \% \mathrm{C}$ and $0.60 \mathrm{wt} . \% \mathrm{Ti}$ was designated as Steel H.

Table 1. Chemical composition of steels studied in this project (wt.\%).

\begin{tabular}{ccccccccc}
\hline Steel Type & C & Si & Mn & Cr & Mo & Ni & Ti & V \\
\hline Steel L & 0.27 & 0.37 & 0.71 & 0.85 & 0.24 & 0.022 & 0.40 & 0.01 \\
Steel H & 0.39 & 0.83 & 1.28 & 0.68 & 0.33 & 0.46 & 0.60 & 0.01 \\
\hline
\end{tabular}

Oxy-fuel flame cutting was carried out using oxy-acetylene and oxygen gas cylinders. Prior to cutting, the steel plates were stored at room temperature $\left(23^{\circ} \mathrm{C}\right)$ with no preheating applied. The cutting was conducted manually at the speed of $304 \pm 2 \mathrm{~mm} / \mathrm{min}$. Although the steel plate temperature during cutting was not measured, the torch temperature can reach as high as $3480^{\circ} \mathrm{C}[29,30]$. Gas cutting is achieved due to an exothermic chemical reaction occurring in steel that may be heated to a temperature at which the iron will rapidly oxidize in an atmosphere of high purity oxygen [31,32]. Plasma cutting was conducted using a Powermax 80 plasma cutting machine (produced by Hypertherm, Hanover, $\mathrm{NH}$, USA). The samples were cut manually at room temperature $\left(23^{\circ} \mathrm{C}\right)$ with a speed of about $450 \pm 50 \mathrm{~mm} / \mathrm{min}$. The plasma temperature may exceed $20,000^{\circ} \mathrm{C}$. When used for cutting, the plasma gas flow is increased so that the deeply penetrating plasma jet cuts through the material and molten material is removed in the efflux plasma. Water-jet cutting was 
carried out on a Maxiem 1530 machine (produced by Omax, Kent, OH, USA), using the Australian Garnet mesh 80 as an abrasive material. The samples were automatically cut at room temperature $\left(24^{\circ} \mathrm{C}\right)$ with an approximate speed of $128 \mathrm{~mm} / \mathrm{min}$. Evaluation of the HAZ strength and microstructure was carried out using hardness testing and optical and scanning electron microscopy. Up to 10 zones from the cut edge through the HAZ to the base metal were investigated for each of six studied conditions (two steel compositions cut with three cutting methods).

Hardness measurements were carried out on an automatic Matsuzawa Via-F Vickers hardness tester (manufactured by Matsuzawa, Akita, Japan); a $5 \mathrm{~kg}$ load was used for indentation. The hardness profile at the plate mid-thickness from the cut edge towards the base metal was plotted with a $0.5 \mathrm{~mm}$ step size. Each point on the hardness profile was calculated based on five indentations made in the plate through thickness direction.

Microstructure characterization was carried out using mainly optical and scanning electron microscopy (SEM). Optical and SEM sample preparation included polishing with $\mathrm{SiC}$ papers and diamond suspensions followed by etching with $5 \% \mathrm{Nital}$. The grain structure was analyzed using imaging on a Nikon Eclipse LV100ND optical microscope (manufactured by Nikon, Tokyo, Japan). Images were taken at two magnifications: $\times 50$ and $\times 500$ for measurements of HAZ sizes and parameters of coarse Ti-rich particles, respectively. Scanning electron microscopy of grain structure and fine Ti-rich and $\mathrm{Fe}_{3} \mathrm{C}$ particles was carried out using a JEOL JSM-7001F FEG scanning electron microscope (JEOL, Tokyo, Japan) operating at $15 \mathrm{kV}$ of accelerating voltage. Images were taken at $\times 5000$ and $\times 30,000$ to evaluate the grain (martensite lath) sizes and parameters of fine Ti-rich and $\mathrm{Fe}_{3} \mathrm{C}$ particles. The average grain size was evaluated as an equivalent grain diameter. Energy dispersive X-ray spectroscopy (EDS) point analysis and element mapping were conducted to evaluate the chemistry of particles. For each condition: 200-350 coarse Ti-rich particles were measured using optical microscopy, up to 200 martensite laths were measured using SEM imaging, up to 30 particles were studied to access their chemical composition with EDS, and up to 400 of fine Ti-rich and $250-300 \mathrm{Fe}_{3} \mathrm{C}$ particles were studied using analysis of SEM images. A JEOL JEM2010 transmission electron microscope (JEOL, Tokyo, Japan) was used to support the characterization of $\mathrm{Fe}_{3} \mathrm{C}$ particles. Thin foils of $3 \mathrm{~mm}$ diameter were prepared by fine polishing on $\mathrm{SiC}$ papers, followed by dimple grinding and ion milling on Gatan PIPS.

\section{Results}

\subsection{Hardness Profile}

The HAZ width decreased with the cutting method from oxy-fuel to plasma to waterjet (Figure 1). Water-jet produces a negligible heat effect. The HAZ width variation observed by optical microscopy was supported by the measurements of hardness profiles from the cut edge towards the base metal (Figure 2). The hardness profile shape varied with the cutting method and steel composition, although the presence of a hardness minimum at a certain distance from the cut edge was observed previously in welded steels with acicular ferrite and bainite microstructure [33]. In Steel L both oxy-fuel and plasma cutting methods decreased hardness by a maximum of $100 \mathrm{HV}$ from its original hardness of $400 \mathrm{HV}$ (Figure 2a,b); and in Steel H this decrease was slightly higher, by about $130 \mathrm{HV}$ from its original hardness of $500 \mathrm{HV}$ (Figure 2d,e). Oxy-fuel resulted in about 5 and $9 \mathrm{~mm}$ wide HAZ in Steels L and H, respectively. In contrast, plasma cutting produced only $3 \mathrm{~mm}$ wide $\mathrm{HAZ}$ in both steels. In Steel L cut with oxy-fuel the minimum HV point was at about $2 \mathrm{~mm}$ from the cut edge (Figure 2a), although the plasma cutting resulted in the appearance of a minimum HV point at about $1.5 \mathrm{~mm}$ from the cut edge (Figure 2b). In Steel H cut with oxy-fuel the minimum HV point was at about $3 \mathrm{~mm}$ from the cut edge (Figure $2 \mathrm{~d}$ ), and in the plasma cut sample, the minimum HV point was at about $1 \mathrm{~mm}$ from the cut edge (Figure 2e). To explain such an intricate shape of the hardness profiles and their variation with steel composition and cutting method, the following microstructural characterization was undertaken. 

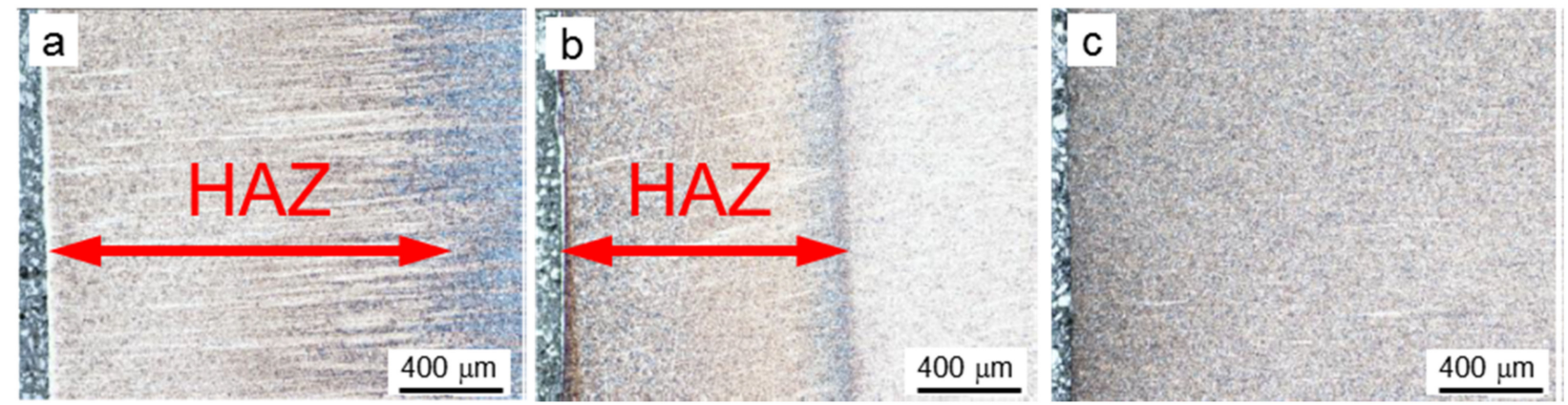

Figure 1. Optical microscopy images of heat affected zone in Steel H cut with (a) oxy-fuel, (b) plasma, and (c) water-jet.
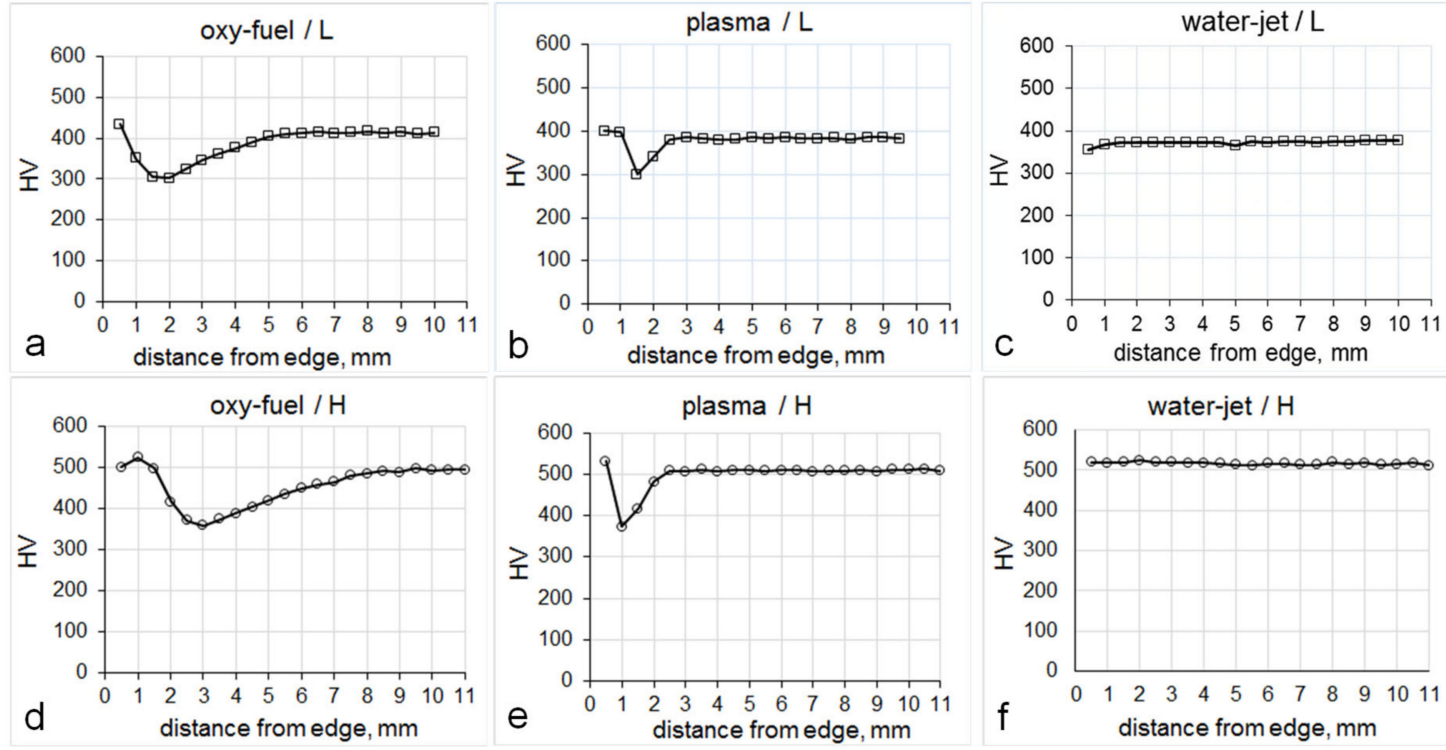

Figure 2. Hardness profiles at the plate mid-thickness position for $(\mathbf{a}-\mathbf{c})$ Steel L and (d-f) Steel H cut with (a,d) oxy-fuel, $(\mathbf{b}, \mathbf{e})$ plasma and $(\mathbf{c}, \mathbf{f})$ water-jet; each point on the hardness profiles is the mean value of 5 indentations made through plate thickness.

\subsection{Grain Structure}

In the as-received condition, both steel grades had a martensitic microstructure. SEM imaging of the cut samples revealed a variation in grain structure with distance from the cut edge.

In the oxy-fuel cut specimens (Figure 3), both steels exhibited a martensitic type of microstructure at the cut edge. A mixed bainite/tempered martensite microstructure was observed at the points of minimum hardness ( 2 and $3 \mathrm{~mm}$ away from the cut edge for Steels $\mathrm{L}$ and $\mathrm{H}$, respectively), martensitic laths have almost disappeared, the grains were of irregular shape. Far away from the cut edge $(10 \mathrm{~mm})$, the microstructure was also of a martensitic type, as could be expected for this steel grade. In the plasma cut specimens (Figure 4), no significant variation in grain structure with the position was observed by SEM in both steels. Formation of complex phase balance in HAZ was reported previously for welded martensitic steels [34] and analyzed using an integrated microstructure modelling approach [35].

Measurements of the average grain size (equivalent diameter of martensite laths) are presented in Table 2. In both steels cut by oxy-fuel, the minimum average grain size was observed at the position of minimum hardness $(2$ and $3 \mathrm{~mm}$ from the cut edge for Steels $\mathrm{L}$ and $\mathrm{H}$, respectively). In both steels cut by plasma, the grain size variation with position was within the measurement error. In the water-jet cut samples also no variation in grain 
size with position was observed. Both steels showed similar values of the average grain size in the base plate.

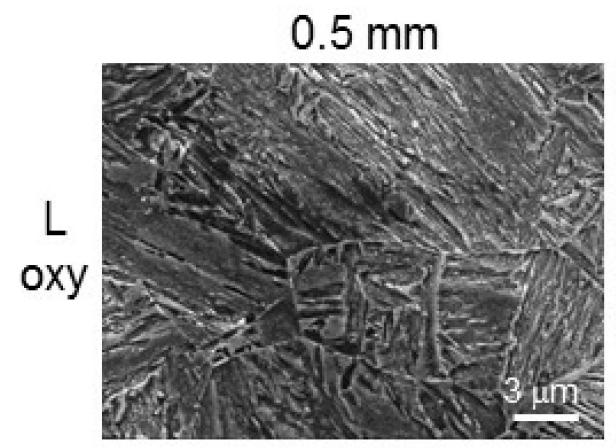

$0.5 \mathrm{~mm}$

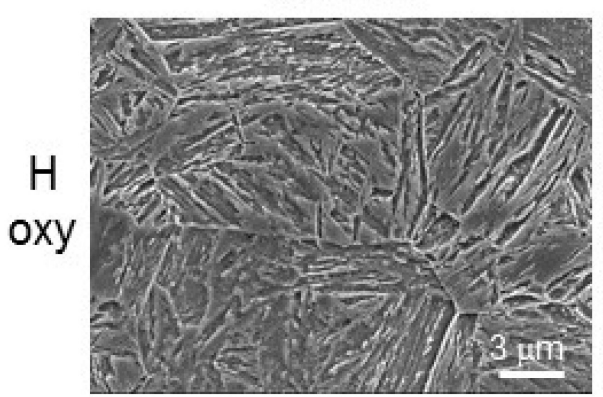

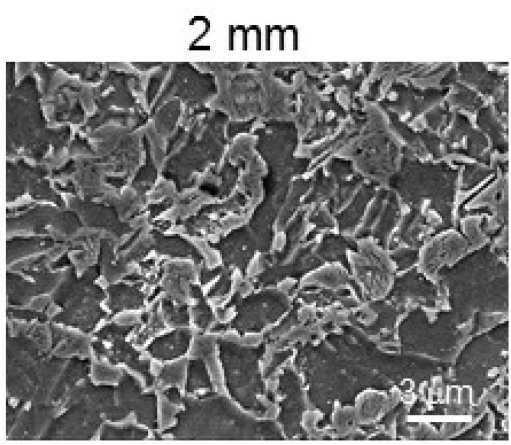

$3 \mathrm{~mm}$

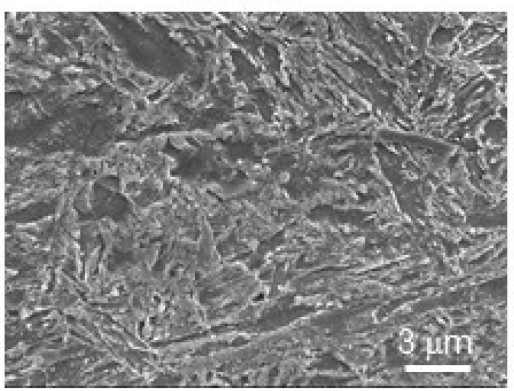

$10 \mathrm{~mm}$

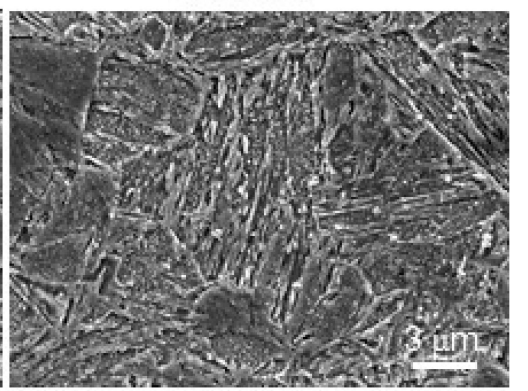

$10 \mathrm{~mm}$

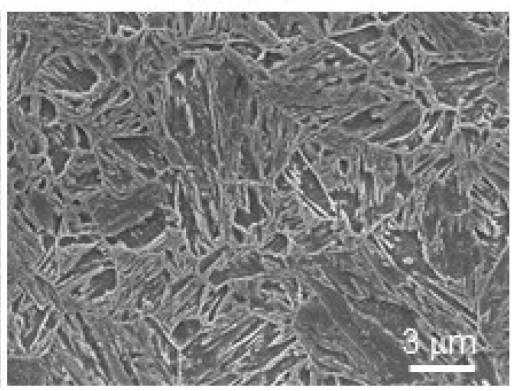

Figure 3. SEM images of grain structure in Steels $\mathrm{L}$ and $\mathrm{H}$ cut using oxy-fuel cutting method: left to right, at the cut edge, point of minimum $\mathrm{HV}$, and far away from the cut edge (base plate).

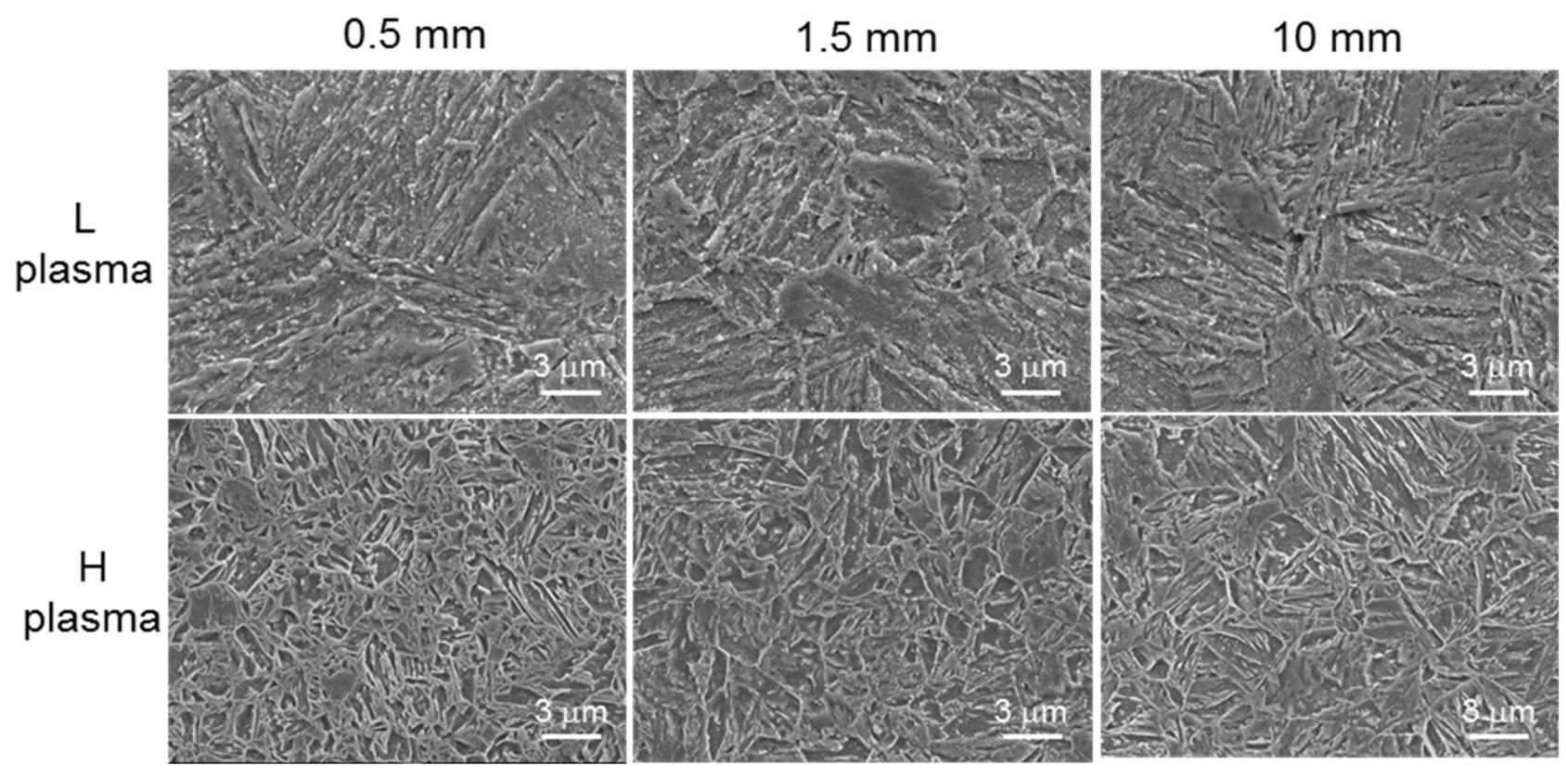

Figure 4. SEM images of grain structure in Steels L and H cut using plasma cutting method: left to right, at the cut edge, point of minimum $\mathrm{HV}$, and far away from the cut edge (base plate). 
Table 2. Average grain size in the studied steels.

\begin{tabular}{|c|c|c|c|c|c|c|}
\hline \multirow{3}{*}{$\begin{array}{c}\text { Steel Grade/ } \\
\text { Cutting Method } \\
\text { Position from } \\
\text { cut edge }\end{array}$} & \multicolumn{3}{|c|}{ Steel L } & \multicolumn{3}{|c|}{ Steel H } \\
\hline & \multicolumn{6}{|c|}{ Oxy-Fuel } \\
\hline & $0.5 \mathrm{~mm}$ & $2.0 \mathrm{~mm}$ & $10 \mathrm{~mm}$ & $0.5 \mathrm{~mm}$ & $3.0 \mathrm{~mm}$ & $10 \mathrm{~mm}$ \\
\hline \multirow[t]{2}{*}{ Average size, $\mu \mathrm{m}$} & $2.3 \pm 0.2$ & $1.9 \pm 0.1$ & $2.3 \pm 0.2$ & $3.0 \pm 0.2$ & $2.1 \pm 0.1$ & $2.5 \pm 0.3$ \\
\hline & \multicolumn{6}{|c|}{ Plasma } \\
\hline $\begin{array}{l}\text { Position from } \\
\text { cut edge }\end{array}$ & $0.5 \mathrm{~mm}$ & $1.5 \mathrm{~mm}$ & $10 \mathrm{~mm}$ & $0.5 \mathrm{~mm}$ & $1.5 \mathrm{~mm}$ & $10 \mathrm{~mm}$ \\
\hline \multirow[t]{2}{*}{ Average size, $\mu \mathrm{m}$} & $2.4 \pm 0.2$ & $2.5 \pm 0.2$ & $2.4 \pm 0.2$ & $2.3 \pm 0.2$ & $2.6 \pm 0.1$ & $2.5 \pm 0.2$ \\
\hline & \multicolumn{6}{|c|}{ Water-Jet } \\
\hline $\begin{array}{l}\text { Position from } \\
\text { cut edge }\end{array}$ & \multicolumn{3}{|c|}{$0.5 \mathrm{~mm}$ and $10 \mathrm{~mm}$} & \multicolumn{3}{|c|}{$0.5 \mathrm{~mm}$ and $10 \mathrm{~mm}$} \\
\hline Average size, $\mu \mathrm{m}$ & \multicolumn{3}{|c|}{$2.6 \pm 0.2$} & \multicolumn{3}{|c|}{$2.5 \pm 0.2$} \\
\hline
\end{tabular}

\subsection{Coarse Ti-Rich Particles}

Optical and SEM imaging revealed three particle types in the studied steels: coarse cuboidal/rectangular/elongated, fine spherical and fine needle-shaped. Presented below is a detailed analysis of these particles in the studied steels and the variation in the particle characteristics with cutting method and distance from the cut edge.

SEM-EDS mapping confirmed the coarse particles $(0.4-6 \mu \mathrm{m})$ to be Ti-rich with various amounts of Mo, V, C, and $\mathrm{N}$ in both steels (Figure 5). The average particle sizes were larger in Steel H (Table 3), which is consistent with higher Ti, Mo and C contents in this steel (Table 1). Larger particles contained a higher nitrogen content. TiN particles are known to precipitate at higher temperatures, compared to TiMoV-rich carbides, therefore TiN usually have more time for growth. The particle parameters near the cut edge varied during cutting (Figure 6): coarse particles dissolved in Steel L, while in Steel $\mathrm{H}$ more particles precipitated. These behaviors seemed to be more pronounced in the samples cut with oxy-fuel compared to the plasma cut.

Table 3. Average parameters of coarse $(\mathrm{TiMoV})(\mathrm{CN})$ particles studied with optical microscopy (at $10 \mathrm{~mm}$ away from the cut edge no heat effect was observed, therefore the microstructure at this position was considered as the as-received).

\begin{tabular}{|c|c|c|c|c|c|c|}
\hline \multirow{2}{*}{$\begin{array}{c}\text { Steel Grade/ } \\
\text { Cutting Method }\end{array}$} & \multicolumn{3}{|c|}{ Steel L } & \multicolumn{3}{|c|}{ Steel H } \\
\hline & \multicolumn{6}{|c|}{ Oxy-Fuel } \\
\hline Position from cut edge & $0.5 \mathrm{~mm}$ & $2.0 \mathrm{~mm}$ & $10 \mathrm{~mm}$ & $0.5 \mathrm{~mm}$ & $3.0 \mathrm{~mm}$ & $10 \mathrm{~mm}$ \\
\hline Average size, $\mu \mathrm{m}$ & $1.6 \pm 0.7$ & $2.5 \pm 0.5$ & $1.8 \pm 0.6$ & $2.9 \pm 1.2$ & $2.2 \pm 0.8$ & $2.9 \pm 0.9$ \\
\hline \multirow[t]{2}{*}{ Number density, $\mu \mathrm{m}^{-2}$} & 0.0020 & 0.0012 & 0.0021 & 0.0039 & 0.0025 & 0.0016 \\
\hline & \multicolumn{6}{|c|}{ Plasma } \\
\hline Position from cut edge & $0.5 \mathrm{~mm}$ & $1.5 \mathrm{~mm}$ & $10 \mathrm{~mm}$ & $0.5 \mathrm{~mm}$ & $1.5 \mathrm{~mm}$ & $10 \mathrm{~mm}$ \\
\hline Average size, $\mu \mathrm{m}$ & $1.9 \pm 0.4$ & $1.5 \pm 0.5$ & $2.1 \pm 0.7$ & $2.5 \pm 0.5$ & $3.2 \pm 1.3$ & $2.8 \pm 0.8$ \\
\hline \multirow[t]{2}{*}{ Number density, $\mu \mathrm{m}^{-2}$} & 0.0021 & 0.0011 & 0.0020 & 0.0033 & 0.0021 & 0.0017 \\
\hline & \multicolumn{6}{|c|}{ Water-Jet } \\
\hline Position from cut edge & $0.5 \mathrm{~mm}$ & \multirow{3}{*}{\multicolumn{2}{|c|}{$\begin{array}{c}10 \mathrm{~mm} \\
1.8 \pm 0.6 \\
0.0019\end{array}$}} & $0.5 \mathrm{~mm}$ & \multicolumn{2}{|c|}{$10 \mathrm{~mm}$} \\
\hline Average size, $\mu \mathrm{m}$ & $2.0 \pm 0.7$ & & & $2.8 \pm 0.8$ & \multicolumn{2}{|c|}{$2.8 \pm 1.0$} \\
\hline Number density, $\mu \mathrm{m}^{-2}$ & 0.0020 & & & 0.0017 & \multicolumn{2}{|c|}{0.0017} \\
\hline
\end{tabular}



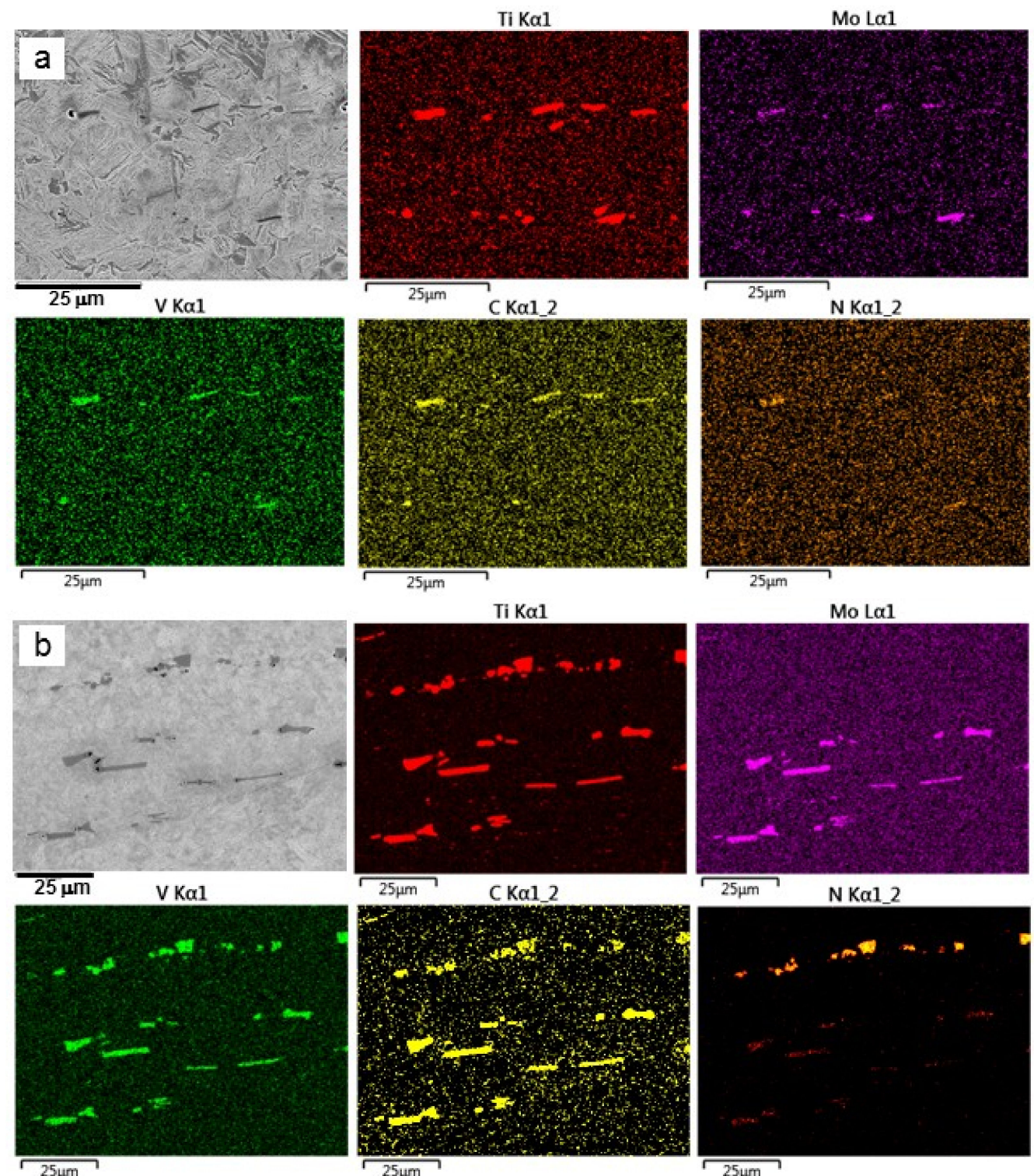

Figure 5. SEM-EDS maps of coarse particles in Steels (a) L and (b) H from selected locations.

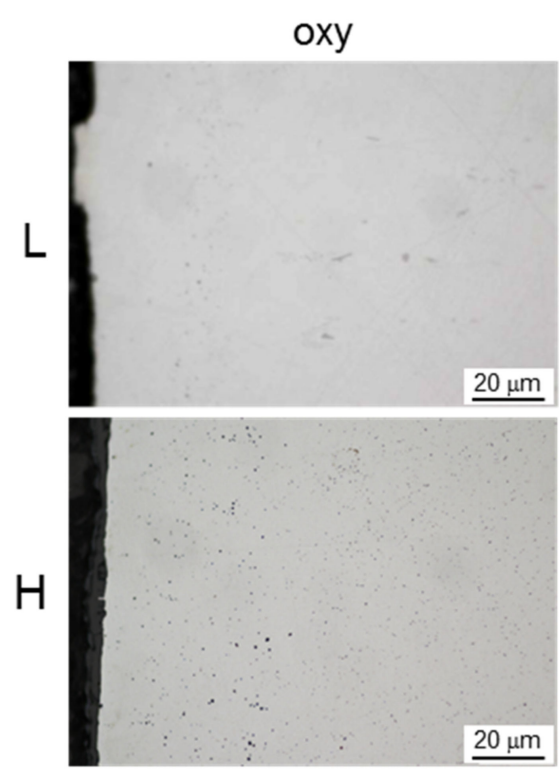

plasma
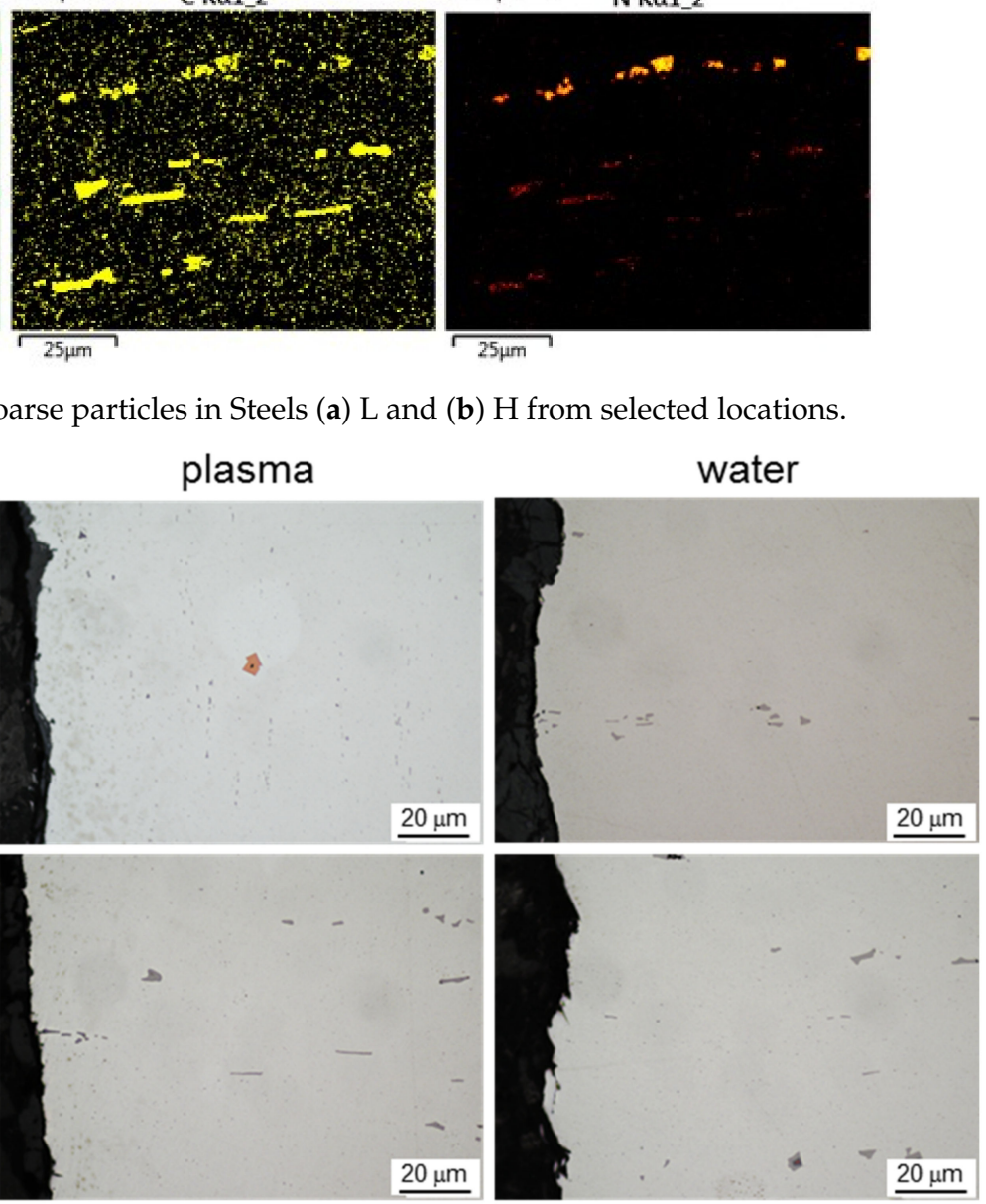

Figure 6. Optical images of Steel L and Steel H cut with the three studied methods (un-etched samples). 
Analysis of the average $(\mathrm{TiMoV})(\mathrm{CN})$ particle parameters (Table 3) suggested the following:

- In Steel L thermal cutting with both methods led to a decrease in the particle number density well below the cut edge surface ( $2 \mathrm{~mm}$ for oxy-fuel and $1.5 \mathrm{~mm}$ for plasma, positions corresponding to minimum hardness); this supports particle dissolution. However, the average particle size at these positions increased after cutting with oxy-fuel and decreased after cutting with plasma. This could be explained if, during cutting with oxy-fuel, the dissolution was more intense (a wider particle size range fully dissolved); and during cutting with plasma, larger particles partially dissolved to smaller sizes. Closer to the cut edge $(0.5 \mathrm{~mm}$ position) the particle number density and average size were similar to that in the base plate. This can be related to shorter times of heat effect associated with faster cooling rates on the surface.

- In contrast, in Steel H cut with both oxy-fuel and plasma the particle number density significantly (near 2 times) increased towards the cut edge; this supports precipitation of new particles and the growth of smaller particles to larger sizes;

- Cutting with water-jet did not lead to any variation in the particle parameters, due to the absence of heat effect.

To further elaborate on the $(\mathrm{TiMoV})(\mathrm{CN})$ particle precipitation kinetics, the number density distributions for various cutting methods and positions have been analyzed (Figure 7). With respect to the cutting method, the following was observed closer to the cut edge ( $0.5 \mathrm{~mm}$ position):

- $\quad$ in Steel L cut with oxy-fuel, dissolution of 0.5-1.0 $\mu \mathrm{m}$ particles occurred (note a decrease in the number density of these particles accompanied by an increase in the density of $<0.5 \mu \mathrm{m}$ particles, Figure $7 \mathrm{a}$ ), although cutting with plasma did not affect the distribution at this position;

- in contrast, in Steel H cut with oxy-fuel new particles precipitated and grew in the $<1.0 \mu \mathrm{m}$ size range (note approximately 4 fold increase in these particles' number density, Figure $7 \mathrm{~b}$ ); and cutting with plasma led to partial dissolution of $0.5-1.0 \mu \mathrm{m}$ particles to $<0.5 \mu \mathrm{m}$ sizes and possible precipitation of new $<0.5 \mu \mathrm{m}$ ones.

- With respect to distance from the cut edge during cutting with oxy-fuel:

- in Steel L the particles in whole size range $(<3 \mu \mathrm{m})$ dissolved, and this was to a greater extent at the $2 \mathrm{~mm}$ position compared to $0.5 \mathrm{~mm}$ position (Figure $7 \mathrm{c}$ );

- in contrast, in Steel $\mathrm{H}<1.0 \mu \mathrm{m}$ particles precipitated at both positions, and this was more intense at $0.5 \mathrm{~mm}$ distance from the cut edge compared to $3.0 \mathrm{~mm}$ (note an increase in the $<1.0 \mu \mathrm{m}$ particle number density by 9 and 5 fold at 0.5 and $3.0 \mathrm{~mm}$ positions, respectively, Figure 7d).

- With respect to distance from the cut edge during cutting with plasma:

- $\quad$ in Steel $\mathrm{L}>1.5 \mu \mathrm{m}$ particles dissolved at $0.5 \mathrm{~mm}$ position and $>0.5 \mu \mathrm{m}$ particles dissolved at $1.5 \mathrm{~mm}$ position (note decreases in their respective number densities, Figure 7e); this means that more particles dissolved at $1.5 \mathrm{~mm}$ position than at $0.5 \mathrm{~mm}$ position, which qualitatively corresponds to the trends observed for cutting with oxy-fuel;

- in contrast, in Steel $\mathrm{H}<1.0 \mu \mathrm{m}$ particles precipitated at both positions and more at $0.5 \mathrm{~mm}$ than at $1.5 \mathrm{~mm}$ distance from the cut edge, which qualitatively corresponds to the behaviour observed during cutting with oxy-fuel.

Comparison of Figure $7 \mathrm{c}$ against e and Figure $7 \mathrm{~d}$ against $\mathrm{f}$ suggests the following interesting point regarding the effect of cutting method. In Steel L cutting with oxy-fuel resulted in the particle dissolution in the whole size range; however, cutting with plasma led to partial dissolution (only $>1.5 \mu \mathrm{m}$ particles dissolved at $0.5 \mathrm{~mm}$ position and $>0.5 \mu \mathrm{m}$ particles dissolved at $1.5 \mathrm{~mm}$ position). In Steel $\mathrm{H}$, particles precipitated and grew during cutting with both methods. However, the increase in $<1.0 \mu \mathrm{m}$ particle number density at $1.5 \mathrm{~mm}$ position (closer to the edge) during cutting with plasma was less (3.5 times) than this at $3.0 \mathrm{~mm}$ position (further away from the edge) during cutting with oxy-fuel (5 times). 
This indicates a more intense heat input during cutting with oxy-fuel leading to a more pronounced variation in the particle parameters.
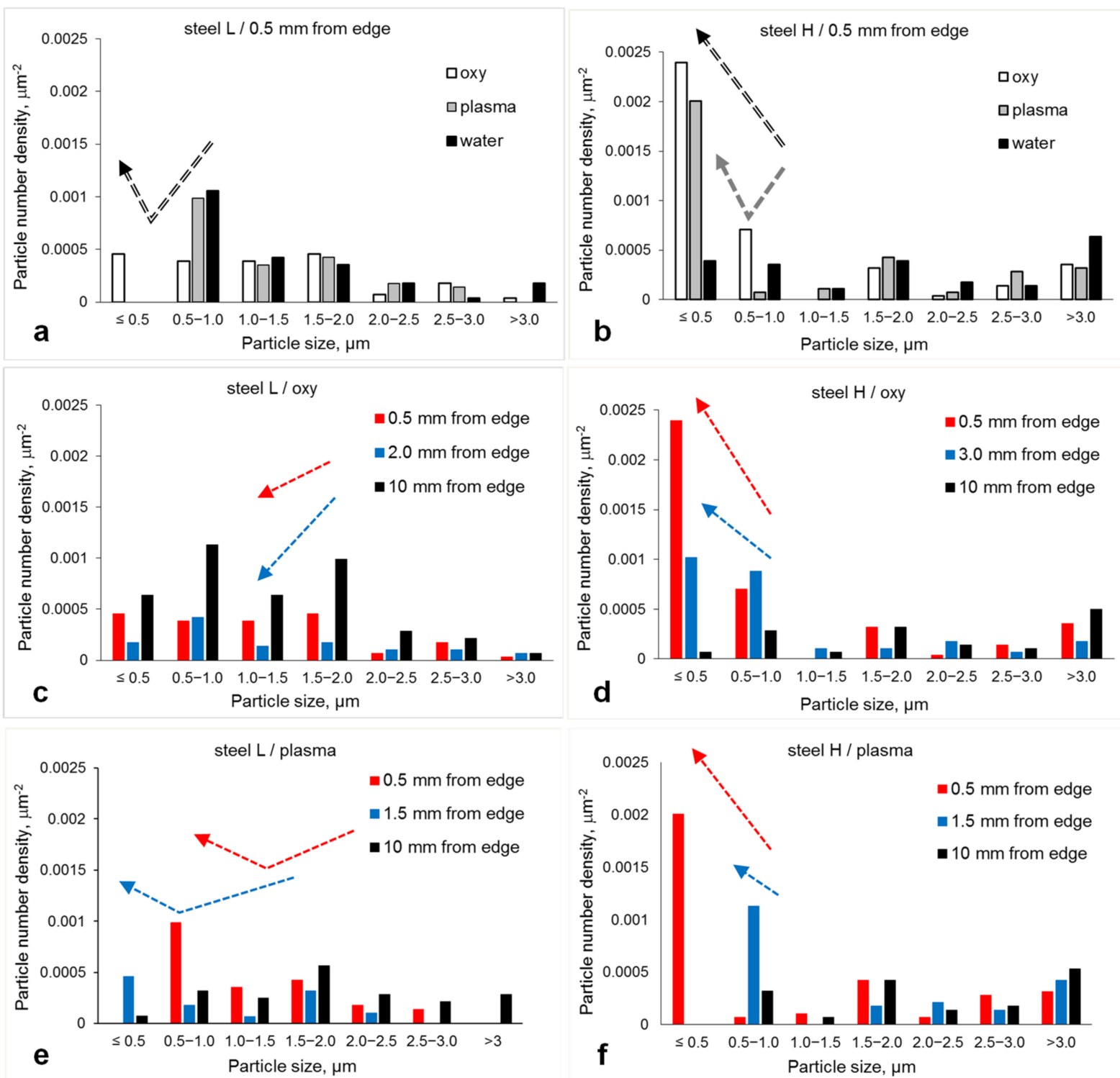

Figure 7. Coarse (TiMoV) $(\mathrm{CN})$ particle number density distributions at $0.5 \mathrm{~mm}$ position from the cut edge in Steels (a) $\mathrm{L}$ and (b) H, for the samples cut with oxy-fuel in Steels (c) L and (d) H, and for the samples cut with plasma in Steels (e) L and (f) $\mathrm{H}$; arrows in $(\mathbf{a}, \mathbf{b})$ indicate the directions of distributions peaks shift for oxy-fuel and plasma cutting methods with respect to the distribution observed for the water jet cutting, and these in (c-f) indicate the directions of distributions peaks shift for $0.5 / 2.0 / 3.0 / 1.5 \mathrm{~mm}$ positions with respect to the distribution for the $10 \mathrm{~mm}$ position.

\subsection{Fine Ti-Rich Particles}

Fine particles were of two types: spherical Ti-rich carbides and carbonitrides with various contents of $\mathrm{Mo}$ and $\mathrm{V}$, and needle-shaped $\mathrm{Fe}_{3} \mathrm{C}$ (Figure 8). Their parameters varied with steel composition, cutting method and distance from the cut edge (Figures 9 and 10). Analysis of fine Ti-rich particle parameters and their variation during cutting with respect to the as-rolled condition has shown that (Table 4):

- in Steel L cut with oxy-fuel (i) the average particle size increased without a significant variation in number density at $0.5 \mathrm{~mm}$ position, and (ii) both the average particle size and their number density increased at $2 \mathrm{~mm}$ position. These might be explained if the growth of fine Ti-rich particles occurred. However, partially dissolving coarse 
(TiMoV) $(\mathrm{CN})$ particles (discussed above) could also contribute to the increase in size and number density of fine Ti-rich ones. During cutting with plasma the number density decreased at both positions and the average size increased at $0.5 \mathrm{~mm}$ position. These support dissolution.

- In Steel H cutting with both methods resulted in the particle number density and average size increasing. These indicate precipitation and coarsening of fine Ti-rich particles.

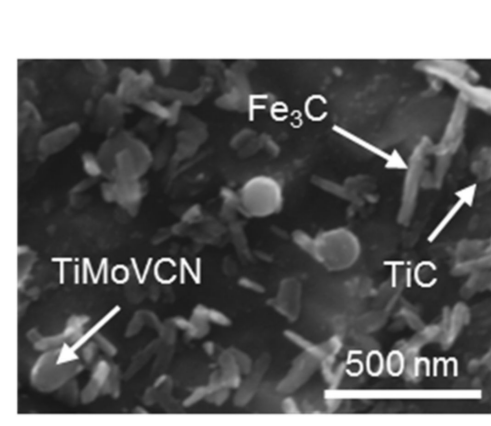

$\vee K \alpha 1$
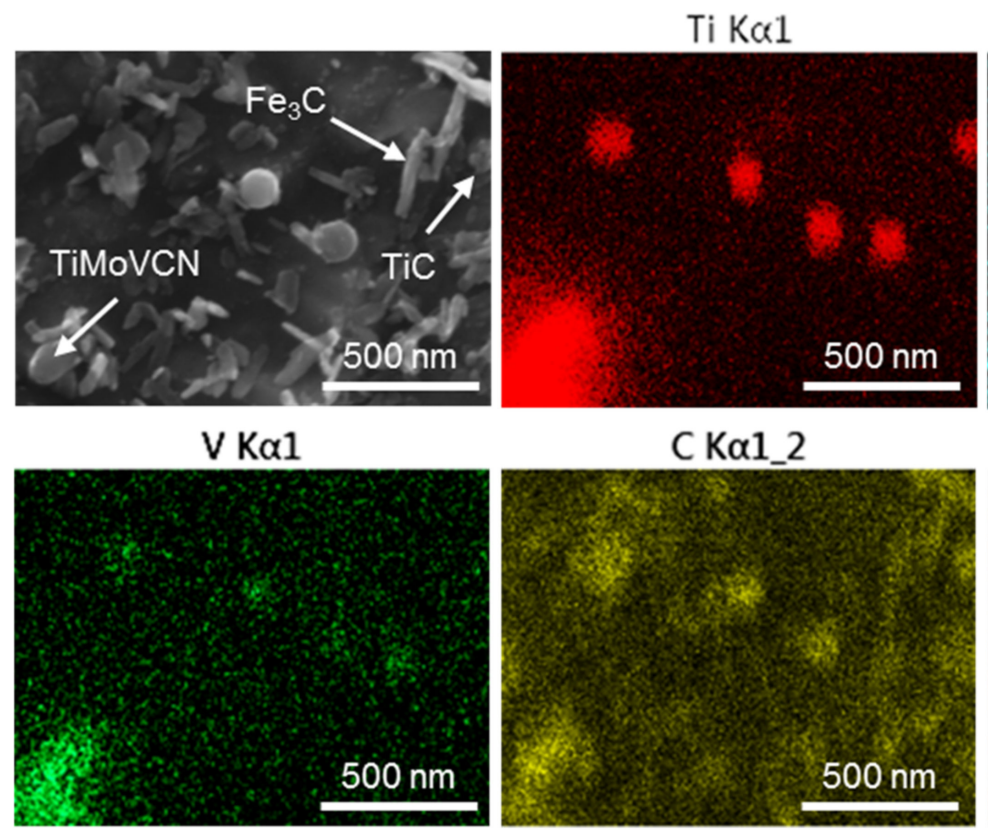

C K $\alpha 1 \_2$
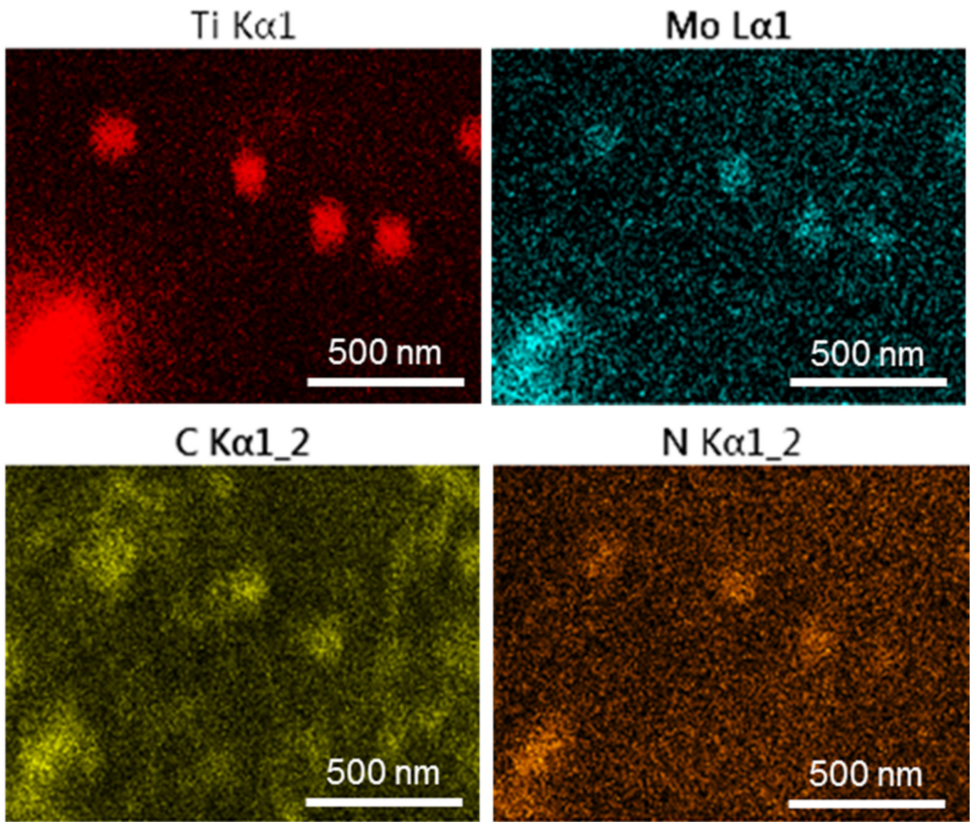

N K $\alpha 12$

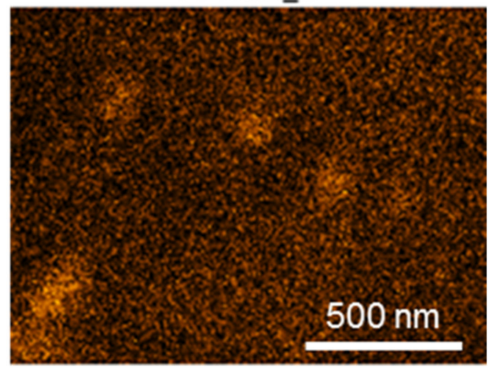

Figure 8. SEM-EDS maps of fine particles observed in both steel grades.

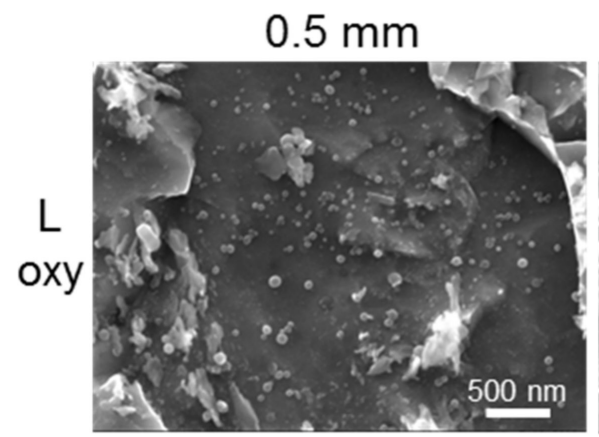

$0.5 \mathrm{~mm}$

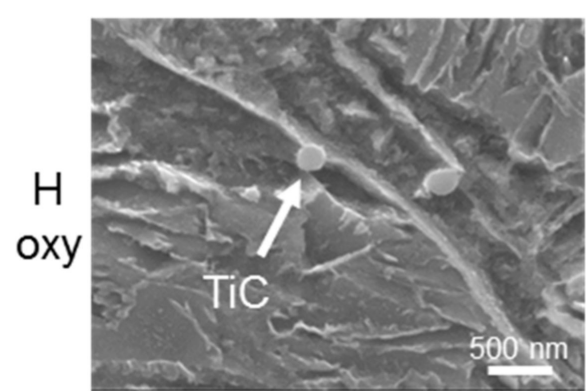

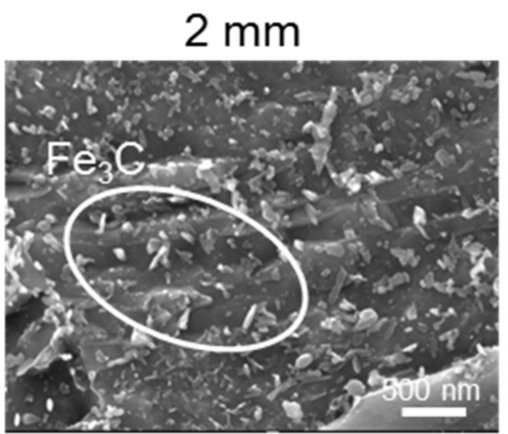

$3 \mathrm{~mm}$

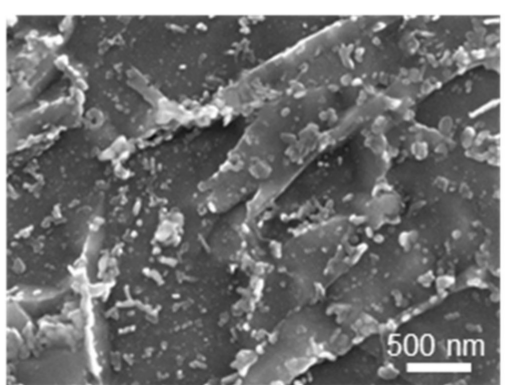

$10 \mathrm{~mm}$

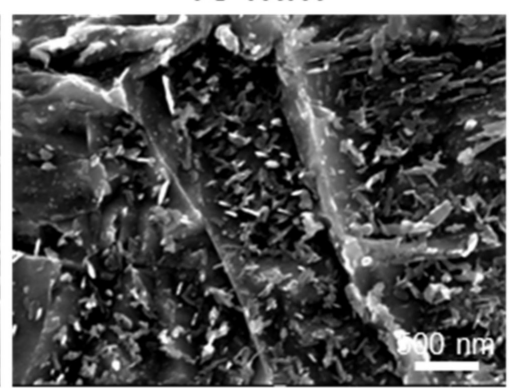

$10 \mathrm{~mm}$

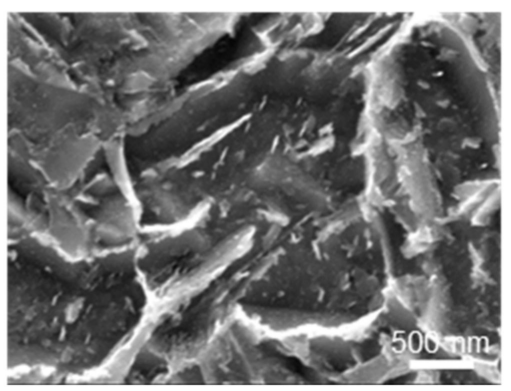

Figure 9. SEM images of fine precipitates in Steels $\mathrm{L}$ and $\mathrm{H}$ cut using oxy-fuel cutting method: left to right, at the cut edge, point of minimum $\mathrm{HV}$, and far away from the cut edge (base plate). 


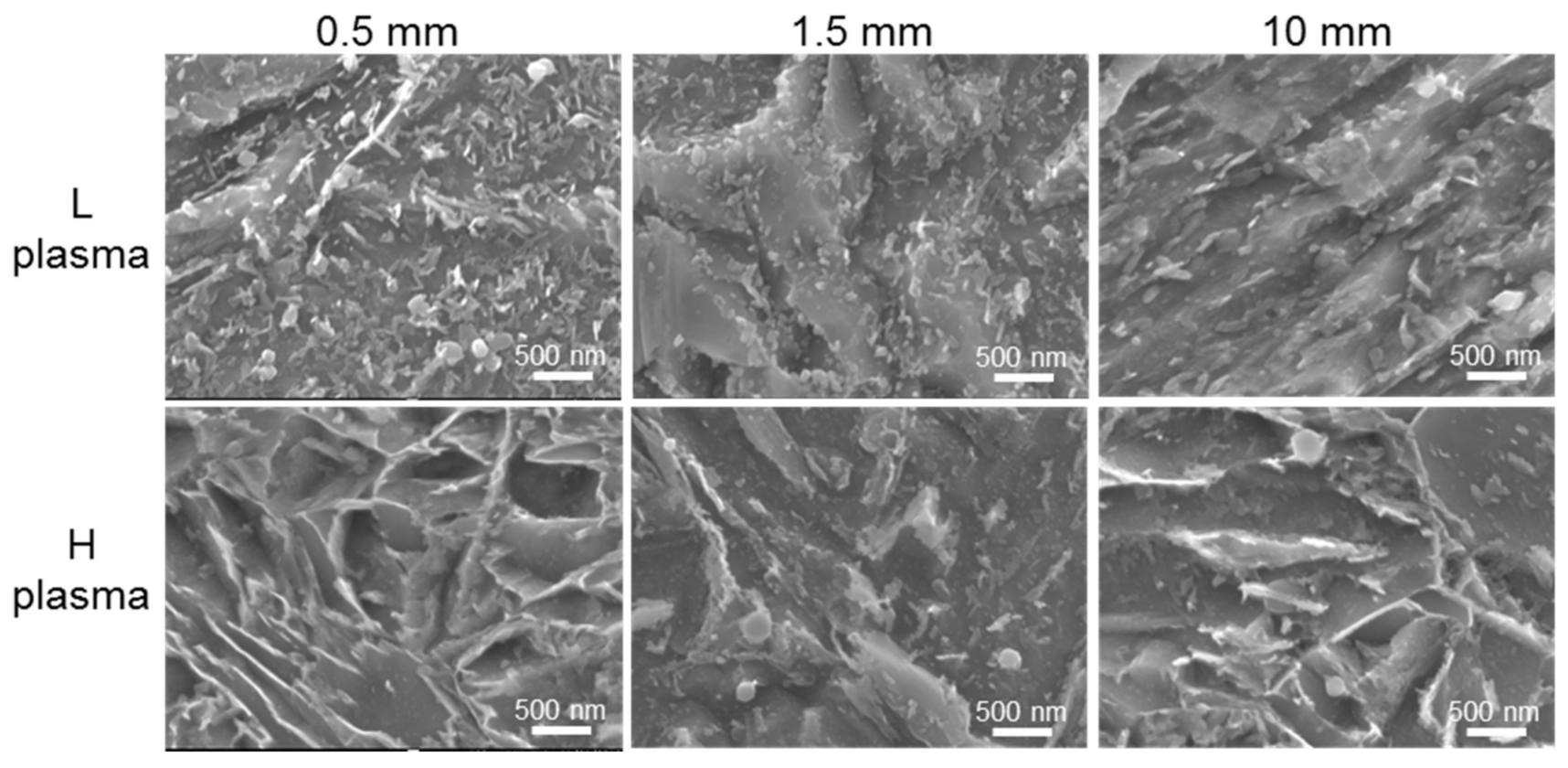

Figure 10. SEM images of fine precipitates in Steels L and H cut using plasma cutting method: left to right, at the cut edge, point of minimum $\mathrm{HV}$, and far away from the cut edge (base plate).

Table 4. Average parameters of fine Ti-rich particles studied with SEM (at $10 \mathrm{~mm}$ away from the cut edge no heat effect was observed, therefore the microstructure at this position was considered as the as-received).

\begin{tabular}{|c|c|c|c|c|c|c|}
\hline \multirow{2}{*}{$\begin{array}{c}\text { Steel Grade/ } \\
\text { Cutting Method }\end{array}$} & \multicolumn{3}{|c|}{ Steel L } & \multicolumn{3}{|c|}{ Steel H } \\
\hline & \multicolumn{6}{|c|}{ Oxy-Fuel } \\
\hline Position from cut edge & $0.5 \mathrm{~mm}$ & $2.0 \mathrm{~mm}$ & $10 \mathrm{~mm}$ & $0.5 \mathrm{~mm}$ & $3.0 \mathrm{~mm}$ & $10 \mathrm{~mm}$ \\
\hline Average size, $\mathrm{nm}$ & $112 \pm 21$ & $93 \pm 30$ & $82 \pm 26$ & $162 \pm 50$ & $104 \pm 42$ & $144 \pm 48$ \\
\hline \multirow[t]{2}{*}{ Number density, $\mu \mathrm{m}^{-2}$} & 1.1 & 2.2 & 1.3 & 0.4 & 0.8 & 0.3 \\
\hline & \multicolumn{6}{|c|}{ Plasma } \\
\hline Position from cut edge & $0.5 \mathrm{~mm}$ & $1.5 \mathrm{~mm}$ & $10 \mathrm{~mm}$ & $0.5 \mathrm{~mm}$ & $1.5 \mathrm{~mm}$ & $10 \mathrm{~mm}$ \\
\hline Average size, $\mathrm{nm}$ & $135 \pm 34$ & $85 \pm 28$ & $83 \pm 23$ & $153 \pm 45$ & $210 \pm 56$ & $150 \pm 43$ \\
\hline Number density, $\mu \mathrm{m}^{-2}$ & 0.8 & 0.5 & 1.4 & 0.6 & 0.6 & 0.3 \\
\hline
\end{tabular}

The particle number density distributions (Figure 11) supported a general dissolution of fine Ti-rich particles in Steel L and their precipitation and growth in Steel $\mathrm{H}$, although there were certain variations with respect to cutting method and position. Thus, in Steel L the $<80 \mathrm{~nm}$ particle number density decreased at $0.5 \mathrm{~mm}$ position after cutting with both oxy-fuel and plasma, and at $1.5 \mathrm{~mm}$ position after cutting with plasma (Figure 11a,c,e), although it slightly increased at $2.0 \mathrm{~mm}$ position after cutting with oxy-fuel. The number density of $>80 \mathrm{~nm}$ particles increased at both positions $(0.5$ and $2.0 / 1.5 \mathrm{~mm})$ after cutting with both methods (Figure 11a,c). These results mean that despite the general dissolution of fine Ti-rich particles, some coarsening could take place in Steel L. In Steel H the $<120 \mathrm{~nm}$ particle number density increased at both positions $(0.5$ and $3.0 / 1.5 \mathrm{~mm})$ after cutting with both methods (Figure 11b,d,f), and it was more pronounced during cutting with oxy-fuel. This clearly indicates precipitation and growth of new Ti-rich particles and is in line with the behaviour of coarse $(\mathrm{TiMoV})(\mathrm{CN})$ particles presented above (Figure $7 \mathrm{~b}, \mathrm{~d}, \mathrm{f})$. 

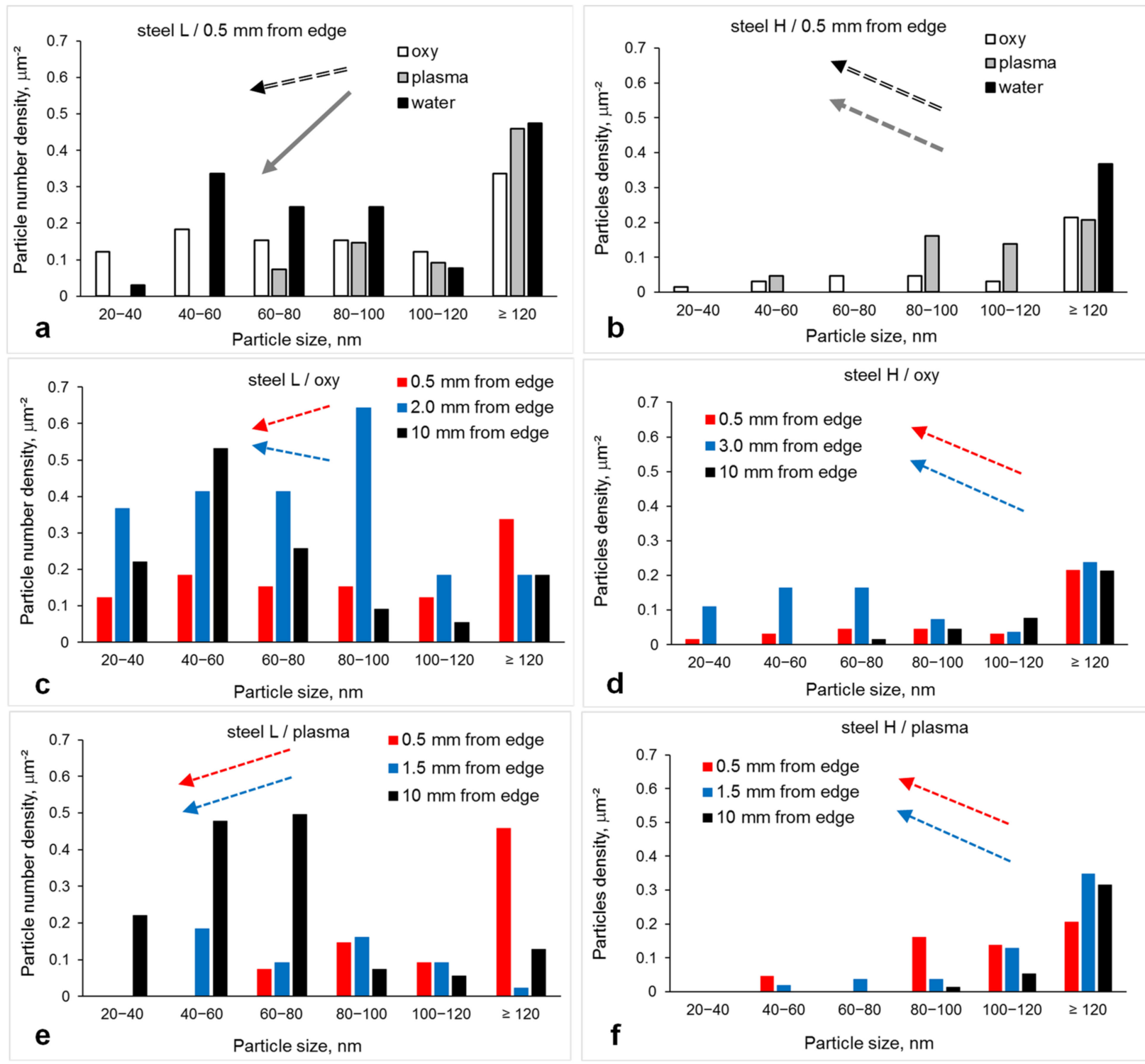

Figure 11. Fine Ti-rich particle number density distributions at $0.5 \mathrm{~mm}$ position from the cut edge for Steels (a) $\mathrm{L}$ and (b) $\mathrm{H}$, for the samples cut with oxy-fuel for Steels (c) L and (d) H, and for the samples cut with plasma in Steels (e) L and (f) H; arrows in $(\mathbf{a}, \mathbf{b})$ indicate the directions of distributions peaks shift for oxy-fuel and plasma cutting methods with respect to the distribution observed for the water jet cutting, and these in (c-f) indicate the directions of distributions peaks shift for 0.5/2.0/3.0/1.5 mm positions with respect to the distribution for the $10 \mathrm{~mm}$ position.

\subsection{Fine $\mathrm{Fe}_{3} \mathrm{C}$ Particles}

SEM imaging revealed the presence of needle-shaped particles with equivalent diameters being in the range of 30-115 $\mathrm{nm}$ for all studied conditions (Figure 12a). SEM-EDS mapping showed increased carbon concentrations in these particles and absence of other alloying elements (Figure 12b). This allowed to suggest that these particles were $\mathrm{Fe}_{3} \mathrm{C}$. In addition to SEM characterization carried out for all studied conditions, a TEM study was performed for the as-received steels (Figure 12c,d). Analysis of the diffraction patens showed the $\mathrm{Fe}_{3} \mathrm{C}$ particles exhibiting Bagaryatskii orientation relationship to the bcc (tempered martensite) matrix: $[001]_{\text {matrix }} \|[321]_{\mathrm{Fe} 3 \mathrm{C}}$ (Figure 12e,f). This can further support their nature as $\mathrm{Fe}_{3} \mathrm{C}$. 

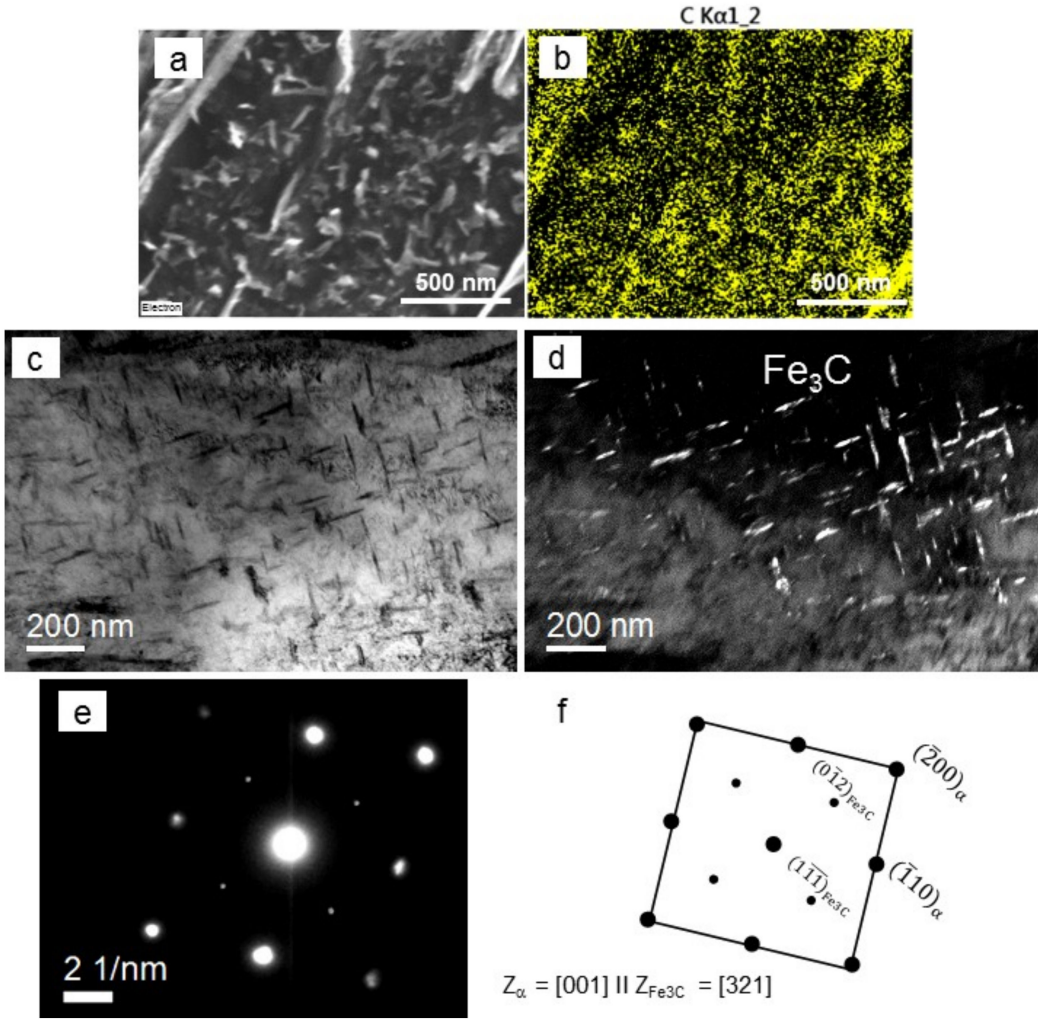

Figure 12. $\mathrm{Fe}_{3} \mathrm{C}$ particles in the base metal of Steel L: (a,b) SEM image with the corresponding EDS carbon map; (c,d) bright and dark field TEM images; (e) diffraction pattern corresponding to images $(\mathbf{c}, \mathbf{d})$; and (f) indexing of the diffraction pattern shown in (e).

In Steel $\mathrm{L}$, the average $\mathrm{Fe}_{3} \mathrm{C}$ particle number density decreased for both cutting methods, and their size could increase slightly during plasma cutting (Table 5). The decrease in number density was higher away from the cut edge, $2.0 \mathrm{~mm}$ position for oxy-fuel cutting and $1.5 \mathrm{~mm}$ for plasma cutting, where a longer thermal effect could be expected. The number density distributions supported a decreasing number of $>40 \mathrm{~nm}$ $\mathrm{Fe}_{3} \mathrm{C}$ particles, and it was more pronounced during cutting with oxy-fuel (Figure 13a,c,e). This evidence points to the dissolution of $\mathrm{Fe}_{3} \mathrm{C}$ particles in Steel $\mathrm{L}$ during thermal cutting.

Table 5. Average parameters of fine $\mathrm{Fe}_{3} \mathrm{C}$ particles studied with SEM (at $10 \mathrm{~mm}$ away from the cut edge no heat effect was observed, therefore the microstructure at this position was considered as the as-received).

\begin{tabular}{ccccccc}
\hline \multirow{2}{*}{$\begin{array}{c}\text { Steel Grade/ } \\
\text { Cutting Method }\end{array}$} & \multicolumn{5}{c}{ Steel L } \\
\cline { 2 - 6 } & \multicolumn{5}{c}{ Oxy-Fuel } \\
\hline Position from cut edge & $0.5 \mathrm{~mm}$ & $2.0 \mathrm{~mm}$ & $10 \mathrm{~mm}$ & $0.5 \mathrm{~mm}$ & $3.0 \mathrm{~mm}$ & $10 \mathrm{~mm}$ \\
Average size, $\mathrm{nm}$ & $37 \pm 9$ & $47 \pm 10$ & $49 \pm 11$ & $52 \pm 9$ & $68 \pm 12$ & $45 \pm 10$ \\
Number density, $\mu \mathrm{mm}^{-2}$ & 2.0 & 1.1 & 2.3 & 0.5 & 0.6 & 1.4 \\
\hline \multicolumn{7}{c}{ Plasma } \\
\hline Position from cut edge & $0.5 \mathrm{~mm}$ & $1.5 \mathrm{~mm}$ & $10 \mathrm{~mm}$ & $0.5 \mathrm{~mm}$ & $1.5 \mathrm{~mm}$ & $10 \mathrm{~mm}$ \\
Average size, $\mathrm{nm}^{-2}$ & $60 \pm 11$ & $67 \pm 9$ & $58 \pm 8$ & $49 \pm 10$ & $51 \pm 11$ & $53 \pm 10$ \\
Number density, $\mu \mathrm{m}^{-2}$ & 2.2 & 1.5 & 2.4 & 1.0 & 1.2 & 1.3 \\
\hline
\end{tabular}



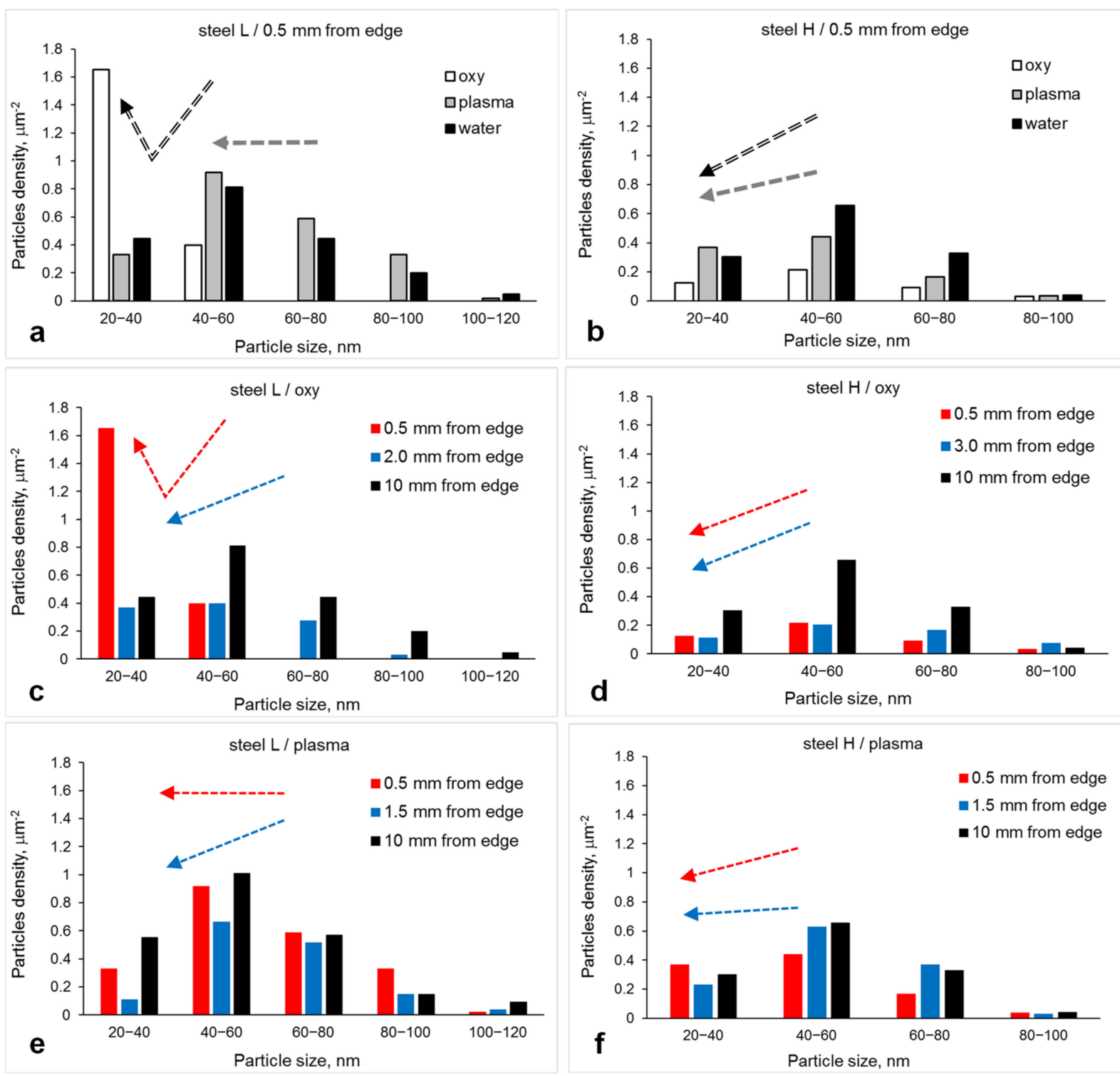

Figure 13. $\mathrm{Fe}_{3} \mathrm{C}$ particle number density distributions at $0.5 \mathrm{~mm}$ position from the cut edge in Steel (a) $\mathrm{L}$ and (b) $\mathrm{H}$; arrows in $(\mathbf{a}, \mathbf{b})$ indicate the directions of distributions peaks shift for oxy-fuel and plasma cutting methods with respect to the distribution observed for the water jet cutting, and these in $(\mathbf{c}-\mathbf{f})$ indicate the directions of distributions peaks shift for 0.5/2.0/3.0/1.5 $\mathrm{mm}$ positions with respect to the distribution for the $10 \mathrm{~mm}$ position.

However, in Steel $\mathrm{H}$ the average particle size increased slightly during cutting with oxy-fuel despite a decrease in number density (Table 5). In addition, during cutting with plasma, no significant variation in the average particle parameters was observed. The number density distributions supported decreasing numbers of particles in the whole size range during oxy-fuel cutting (Figure $13 \mathrm{~b}, \mathrm{~d}, \mathrm{f}$ ), and very minor variations during cutting with plasma. These indicate partial dissolution of $\mathrm{Fe}_{3} \mathrm{C}$ particles in Steel $\mathrm{H}$, more pronounced during cutting with oxy-fuel.

\section{Discussion}

\subsection{Effect of Steel Composition}

The average particle parameters and hardness values with respect to steel composition and cutting method are summarised in Table 6 . In as-received condition (10 mm away from the cut edge), the grain size was similar in both steels, the number densities of coarse $(\mathrm{TiMoV})(\mathrm{CN})$ and fine Ti-rich particles were higher in Steel L (although their 
sizes were larger in Steel $\mathrm{H}$, Tables 3 and 4), and the number densities of $\mathrm{Fe}_{3} \mathrm{C}$ particles were also higher in Steel L. Larger sizes of coarse $(\mathrm{TiMoV})(\mathrm{CN})$ and fine Ti-rich particles correspond to higher contents of Ti, Mo and C in Steel H (Table 1). However, lower number densities of all particle types in Steel $\mathrm{H}$ is an unusual result. Higher concentrations of $\mathrm{Ti}$ and $\mathrm{C}$ increase the solubility products of TiN and TiC particles [36,37] and their precipitation start temperatures, traditionally this leads to higher particle number densities at room temperature [38-40]. Probably, the rolling of Steel $\mathrm{H}$ was conducted at high speed, accelerated cooling might also have been used at the end of the hot rolling cycle. These techniques would result in the matrix super-saturation with $\mathrm{Ti}$, Mo and $\mathrm{C}$ and solid solution strengthening. Consequently, the hardness of Steel $\mathrm{H}$ was higher than that of Steel L.

Table 6. Correlation of the microstructural parameters and hardness to steel grade and cutting method.

\begin{tabular}{|c|c|c|c|c|c|c|c|}
\hline \multirow{2}{*}{\multicolumn{2}{|c|}{ Steel Grade/Cutting Method }} & \multicolumn{3}{|c|}{ Steel L } & \multicolumn{3}{|c|}{ Steel H } \\
\hline & & \multicolumn{6}{|c|}{ Oxy-Fuel } \\
\hline Position from $\mathrm{cl}$ & dge & $0.5 \mathrm{~mm}$ & $2.0 \mathrm{~mm}$ & $10 \mathrm{~mm}$ & $0.5 \mathrm{~mm}$ & $3.0 \mathrm{~mm}$ & $10 \mathrm{~mm}$ \\
\hline Average grain si & $\mu \mathrm{m}$ & $2.3 \pm 0.2$ & $1.9 \pm 0.1$ & $2.3 \pm 0.2$ & $3.0 \pm 0.1$ & $2.1 \pm 0.1$ & $2.5 \pm 0.3$ \\
\hline \multirow{3}{*}{ Number density, $\mu \mathrm{m}^{-2}$} & $\begin{array}{l}\text { Coarse } \\
\text { Ti-rich }\end{array}$ & 0.0020 & 0.0012 & 0.0021 & 0.0039 & 0.0025 & 0.0016 \\
\hline & Fine Ti-rich & 1.1 & 2.2 & 1.3 & 0.4 & 0.8 & 0.3 \\
\hline & $\mathrm{Fe}_{3} \mathrm{C}$ & 2.0 & 1.1 & 2.3 & 0.5 & 0.6 & 1.4 \\
\hline \multicolumn{2}{|c|}{ Hardness, HV } & $430 \pm 8$ & $300 \pm 5$ & $410 \pm 10$ & $520 \pm 10$ & $359 \pm 7$ & $500 \pm 4$ \\
\hline & & \multicolumn{6}{|c|}{ Plasma } \\
\hline \multirow{2}{*}{\multicolumn{2}{|c|}{$\begin{array}{l}\text { Position from cut edge } \\
\text { Average grain size, } \mu \mathrm{m}\end{array}$}} & $0.5 \mathrm{~mm}$ & $1.5 \mathrm{~mm}$ & $10 \mathrm{~mm}$ & $0.5 \mathrm{~mm}$ & $1.5 \mathrm{~mm}$ & $10 \mathrm{~mm}$ \\
\hline & & $2.4 \pm 0.2$ & $2.5 \pm 0.2$ & $2.4 \pm 0.2$ & $2.3 \pm 0.2$ & $2.6 \pm 0.1$ & $2.5 \pm 0.2$ \\
\hline \multirow{3}{*}{ Number density, $\mu \mathrm{m}^{-2}$} & $\begin{array}{l}\text { Coarse } \\
\text { Ti-rich }\end{array}$ & 0.0021 & 0.0011 & 0.0020 & 0.0033 & 0.0021 & 0.0017 \\
\hline & Fine Ti-rich & 0.8 & 0.5 & 1.4 & 0.6 & 0.6 & 0.3 \\
\hline & $\mathrm{Fe}_{3} \mathrm{C}$ & 2.2 & 1.5 & 2.4 & 1.0 & 1.2 & 1.3 \\
\hline \multicolumn{2}{|c|}{ Hardness, HV } & $400 \pm 8$ & $300 \pm 5$ & $385 \pm 6$ & $530 \pm 4$ & $417 \pm 4$ & $505 \pm 5$ \\
\hline
\end{tabular}

During cutting with oxy-fuel, the Ti-rich particles exhibited different types of precipitation kinetics in the two steels. Thus, in Steel L the number density of coarse (TiMoV)(CN) particles decreased and that of fine Ti-rich particles increased towards the cut edge. This indicates dissolution of the coarse particles to smaller sizes in Steel L. In contrast, in Steel $\mathrm{H}$, the number densities of both coarse and fine Ti-rich particles increased towards the cut edge. This indicates precipitation and growth of new particles in Steel H. Such a discrepancy in the Ti-rich particle behaviour can be related to two reasons: (i) Ti, Mo and $\mathrm{C}$ concentrations in the matrix were higher in Steel $\mathrm{H}$; during thermal cutting the $\mathrm{Ti}$, Mo and $\mathrm{C}$ atoms diffused to the existing particles contributing to their size growth and diffused to each other to form new Ti-rich particles; and (ii) the solubility temperature of Ti-rich particles was lower in Steel L; this would result in fewer undissolved coarse particles in Steel $\mathrm{L}$ after heating during cutting. In fact, the solubility equation $\log [\mathrm{Ti}] \cdot[\mathrm{C}]=2.75-7000 / \mathrm{T}$ presented in [37] gave $1575{ }^{\circ} \mathrm{C}$ and $1942{ }^{\circ} \mathrm{C}$ for TiC dissolution temperature in Steel $\mathrm{L}$ and $\mathrm{H}$, respectively. A decreasing number density of $\mathrm{Fe}_{3} \mathrm{C}$ particles in both steels (nearly twofold drop) coincided with an increasing number density of Ti-rich particles. Dissolution of cementite in favour of alloying element carbide precipitation was observed following tempering of martensite [41].

In both steels, the grain size slightly decreased below the cut edge $(2.0$ and $3.0 \mathrm{~mm}$ positions in Steels $\mathrm{L}$ and $\mathrm{H}$, respectively) due to recrystallization [42]. However, the microstructure resembled freshly transformed martensite closer to the edge $(0.5 \mathrm{~mm}$ position, Figure 3). This could be explained if, due to heating from oxy-fuel, the original martensite closer to the edge transformed to austenite and back to martensite during cooling. The 
grain size at the edge $(0.5 \mathrm{~mm}$ position) was slightly larger in Steel $\mathrm{H}(3.0 \mu \mathrm{m})$ compared to Steel L $(2.3 \mu \mathrm{m})$. This can be associated with two reasons: (i) fine Ti-rich particles exhibiting a lower number density in Steel $\mathrm{H}$ were less effective in retardation of austenite grain growth in Steel H compared to Steel L; and (ii) the ferrite to austenite transformation temperature was lower in Steel $\mathrm{H}, 770-785^{\circ} \mathrm{C}$, than in Steel $\mathrm{L}, 835-845^{\circ} \mathrm{C}$ (calculated using various formulas presented in $[43,44]$ ). The latter would give added time for the matrix to be in austenitic condition and, consequently, more time for austenite grain growth.

In spite of decreasing grain size and increasing number density of fine Ti-rich particles, hardness decreased in Steel $\mathrm{L}$ at the $2.0 \mathrm{~mm}$ position. This corresponds to the decrease in the number density of coarse $(\mathrm{TiMoV})(\mathrm{CN})$ and $\mathrm{Fe}_{3} \mathrm{C}$ particles. In Steel $\mathrm{H}$, a minimum hardness was also observed; although, in contrast to Steel L, the number density of coarse $(\mathrm{TiMoV})(\mathrm{CN})$ particles increased in addition to increasing number density of fine Ti-rich particles. This supports the following conclusions: (i) the grain structure recovery (dislocation annihilation) and recrystallization in the HAZ can significantly contribute to a hardness decrease, irrespective of the particle precipitation kinetics, because the number of dislocation-obstacle interaction sites is responsible for strength, and not the number of particles dispersed in the matrix; (ii) precipitation of coarse $(\mathrm{TiMoV})(\mathrm{CN})$ and fine Ti-rich particles cannot fully compensate for the dissolution of $\mathrm{Fe}_{3} \mathrm{C}$, and (iii) solution depletion in C (due to precipitation of excessive amount of fine Ti-rich carbides) is detrimental for hardness.

Closer to the cut edge ( $0.5 \mathrm{~mm}$ position), the hardness increased in both steels. $\mathrm{Ob}$ viously, a reverse martensite-austenite-martensite transformation resulted in a higher dislocation density at the cut edge in both steels. Lower heat effect times, due to faster cooling of the edge compared to the $2.0 \mathrm{~mm}$ position, resulted in less severe particle dissolution in Steel L. In Steel H, significant precipitation of coarse $(\mathrm{TiMoV})(\mathrm{CN})$ particle might have contributed to the hardness increase at the edge.

During cutting with plasma, in Steel L the number densities of coarse $(\mathrm{TiMoV})(\mathrm{CN})$, fine Ti-rich and $\mathrm{Fe}_{3} \mathrm{C}$ particles decreased at the $1.5 \mathrm{~mm}$ position from the cut edge (simultaneously with a size growth of fine Ti-rich and $\mathrm{Fe}_{3} \mathrm{C}$ particles, Tables 4 and 5). This indicates dissolution of all particles in Steel L. In contrast, in Steel $\mathrm{H}$, the $(\mathrm{TiMoV})(\mathrm{CN})$ and fine Ti-rich particles precipitated and grew, although $\mathrm{Fe}_{3} \mathrm{C}$ dissolved, and these behaviours were more pronounced closer to the edge (at $0.5 \mathrm{~mm}$ position). This is in line with the matrix super-saturation with $\mathrm{Ti}, \mathrm{Mo}$ and $\mathrm{C}$ in the as-rolled condition.

Despite different kinetics of (TiMoV) $(\mathrm{CN})$ and fine Ti-rich particles, the minimum hardness at the $1.5 \mathrm{~mm}$ position was observed in both steels. This may indicate a variation in strengthening mechanisms utilised to produce the studied steels: in addition to phase balance (namely formation of martensite), strengthening of Steel L relied on particle precipitation, and when their number densities decrease, the strength decreases; while in Steel $\mathrm{H}$, the strengthening from solute $\mathrm{C}, \mathrm{N}$ and Mo atoms [45-47], Ti-Mo-C atom clusters [48-50] and $<20 \mathrm{~nm}$ TiC particles [51-53] (not studied here) could be significant.

\subsection{Effect of Cutting Method}

In Steel L (i) the grain size decreased during oxy-fuel cutting below the cut edge ( $2.0 \mathrm{~mm}$ position), but did not show a variation during plasma cutting; (ii) coarse $(\mathrm{TiMoV})(\mathrm{CN})$ particles dissolved during both cutting methods to similar remaining number density values; (iii) fine Ti-rich particles showed increasing number densities below the cut edge ( $2.0 \mathrm{~mm}$ position) after cutting with oxy-fuel (which could result from the dissolution of $\mathrm{Fe}_{3} \mathrm{C}$ in favour of precipitation of fine Ti-rich particles), but dissolved during plasma cutting; (iv) $\mathrm{Fe}_{3} \mathrm{C}$ particles dissolved below the cut edge $(2.0$ or $1.5 \mathrm{~mm}$ position for oxy-fuel and plasma) during cutting with both methods, although more during cutting with oxy-fuel; and (v) hardness showed a minimum below the cut edge for both methods, although a greater decrease and at a larger distance occurred after cutting with oxy-fuel. Together with a wider HAZ, all these observations indicate a more pronounced heat effect during cutting with oxy-fuel. A high tempering effect during cutting with oxy-fuel was 
observed recently in low carbon steels [54-56]. In spite of higher temperatures applied during cutting with plasma $\left(20,000{ }^{\circ} \mathrm{C}\right.$ [32]) compared to oxy-fuel $\left(3500^{\circ} \mathrm{C}\right.$ [30]), a narrower $\mathrm{HAZ}$ and less severe softening were observed in Steel $\mathrm{L}$ during plasma cutting. This can be related to two reasons: (i) a faster processing speed, giving less time for heat transfer towards the base plate; and (ii) melting down and removal of the heat affected material from the edge.

In Steel H (i) the grain size slightly decreased below the cut edge ( $3.0 \mathrm{~mm}$ position) during oxy-fuel cutting, although no significant variation in grain size was observed after plasma cutting; (ii) coarse and fine Ti-rich particles precipitated for both cutting methods; (iii) $\mathrm{Fe}_{3} \mathrm{C}$ particles dissolved for both cutting methods, although to a greater extent for oxyfuel; and (iv) hardness showed a minimum below the cut edge for both methods, although a greater decrease and at a larger distance occurred after cutting with oxy-fuel. Similar to Steel $\mathrm{L}$, in Steel $\mathrm{H}$, the oxy-fuel cutting method produced a larger thermal effect on the cut edge than the plasma cutting method. However, the edge hardness of Steel H remained higher than that of Steel L for both cutting methods. This is related to the variation in steel compositions: (i) more highly alloyed Steel $\mathrm{H}$ exhibited larger sizes of coarse and fine Ti-rich particles, which would be more stable with respect to dissolution [57-59]; and (ii) potentially higher solute concentrations of Ti, Mo and C in the Steel $\mathrm{H}$ matrix not only retarded recovery but also facilitated solid solution strengthening and precipitation and growth of new particles during thermal cutting [60-62].

\section{Conclusions}

Thermal cutting of two Ti-alloyed martensitic steels containing 0.27C-0.40Ti and 0.39C$0.60 \mathrm{Ti}(\mathrm{wt} . \%)$ altered the microstructure and hardness near the cut edge in both steels. This must be taken into account during edge preparation for welding and structure fabrication.

1. With respect to practical aspects of this work, the following may be concluded. In both steels, the maximum decrease in hardness due to thermal cutting with oxy-fuel or plasma may reach $25 \%$ of the respective original hardness: $100 \mathrm{HV}$ down from the original $400 \mathrm{HV}$ in the lower alloyed steel with $0.27 \mathrm{C}-0.40 \mathrm{Ti}$ (wt.\%) and $130 \mathrm{HV}$ down from the original $500 \mathrm{HV}$ in the more highly alloyed steel with $0.39 \mathrm{C}-0.60 \mathrm{Ti}$ (wt.\%). Cutting with oxy-fuel produced a wider heat affected zone (HAZ) (5 and $9 \mathrm{~mm}$ for the lower and higher alloyed steels, respectively), compared to plasma cutting (about $3 \mathrm{~mm}$ for both steels). No HAZ, microstructure or hardness variation was observed for the water-jet cutting method. Therefore, in practice cutting of Ti-alloyed martensitic steels should be conducted using water-jet. Plasma cutting is acceptable if certain precautions are put in place, in particular a set maximum cutting speed. This would reduce the time of heat effect and potential implications on microstructure and properties.

2. With respect to microstructure-properties variation with steel composition and cutting method, the following fundamental outcomes can be highlighted. Maximum tempering of microstructure (minimum absolute hardness values or maximum relative decrease in hardness associated with the tempering) was observed in the lower alloyed steel (due to weaker solid solution and precipitation strengthening) cut with oxy-fuel (characterised by higher heat input). Minimum tempering occurred in the more highly alloyed steel (due to stronger solid solution and precipitation strengthening) cut with plasma (characterised by lower heat input). In the lower alloyed steel, coarse $(\mathrm{TiMoV})(\mathrm{CN})$, fine Ti-rich and $\mathrm{Fe}_{3} \mathrm{C}$ dissolved during thermal cutting. In the more highly alloyed steel, both coarse $(\mathrm{TiMoV})(\mathrm{CN})$ and fine Ti-rich particles precipitated and grew, while $\mathrm{Fe}_{3} \mathrm{C}$ dissolved. These discrepancies in the particle precipitation kinetics can be associated with the variation in steel composition: higher $\mathrm{Ti}$, Mo and $\mathrm{C}$ contents in the more highly alloyed steel (and concentrations of these elements in the matrix) increased the solubility temperatures of existing precipitates and the driving force for precipitation and growth of new particles. Precipitation of Ti-rich particles in the more highly alloyed steel during thermal cutting provided 
precipitation strengthening, which compensated for the softening associated with dislocation annihilation and dissolution of $\mathrm{Fe}_{3} \mathrm{C}$.

Author Contributions: Conceptualization, C.R.K., H.L. and D.Y.; Methodology, A.G.K. and M.R.; Investigation, M.R. and A.G.K.; Data Curation, A.G.K. and M.R.; Writing-Original Draft Preparation, A.G.K. and M.R.; Project Administration, C.R.K., H.L. and D.Y.; Funding Acquisition, C.R.K., H.L. and D.Y. All authors have read and agreed to the published version of the manuscript.

Funding: This project was funded through the ARC Research Hub for Australian Steel Manufacturing under the Industrial Transformation Research Hubs scheme (Project ID: IH130100017), together with BlueScope Steel and Bisalloy Steels. The microscopy was carried out using JEOL JSM-7001F FEGSEM (supported by grant LE0882613) and JEOL JEM-2010 TEM (supported by grant LE0237478) microscopes at the Electron Microscopy Centre at the University of Wollongong.

Data Availability Statement: The data presented in this study are available on request from the corresponding author.

Conflicts of Interest: The authors declare no conflict of interest.

\section{References}

1. Xu, L.; Kennon, N.F. A study of the abrasive wear of carbon steels. Wear 1991, 148, 101-112. [CrossRef]

2. Maweja, K.; Stumpf, W. The design of advanced performance high strength low-carbon martensitic armour steels: Microstructural considerations. Mater. Sci. Eng. A 2008, 480, 160-166. [CrossRef]

3. Karagöz, S.; Atapek, Ş.H.; Yilmaz, A. Microstructural and fractographical studies on quenched and tempered armor steels. Materialpruefung 2010, 52, 316-322. [CrossRef]

4. Jena, P.K.; Mishra, B.; Rameshbabu, M.; Babu, A.; Singh, A.K.; Sivakumar, K.; Bhat, T.B. Effect of heat treatment on mechanical and ballistic properties of a high strength armour steel. Int. J. Impact. Eng. 2010, 37, 242-249. [CrossRef]

5. El-Batahgy, A.M.; Miura, T.; Ueji, R.; Fujii, H. Investigation into feasibility of FSW process for welding $1600 \mathrm{MPa}$ quenched and tempered steel. Mater. Sci. Eng. A. 2016, 651, 904-913. [CrossRef]

6. Alexandrov, B.; Theis, K.; Streitenberger, M.; Herold, H.; Martinek, I. Cold cracking in weldments of steel S 690 QT. Weld. World 2005, 49, 64-73. [CrossRef]

7. Magudeeswaran, G.; Balasubramanian, V.; Madhusudhan, R.G. Hydrogen induced cold cracking studies on armour grade high strength, quenched and tempered steel weldments. Int. J. Hydrog. Energy 2008, 33, 1897-1908. [CrossRef]

8. Kuzmikova, L.; Callaghan, M.; Larkin, N.; Scott, R.; DeJong, R.; Li, H.; Norrish, J. A study of a continuous cooling behaviour and effect of preheat and interpass temperature on the HAZ of high strength quenched and tempered steel. In Proceedings of the International Institute of Welding Annual Assembly, Istanbul, Turkey, 15-16 July 2010, paper IX-2352-10.

9. Barenyi, I.; Hires, O.; Liptak, P. Degradation of mechanical properties of armoured steels after its welding. In Proceedings of the International Conference AFASES2011, Brasov, Romania, 26-28 May 2011; pp. 845-848.

10. Kuzmikova, L.; Larkin, N.; Pan, Z.; Callaghan, M.; Li, H.; Norrish, J. Investigation into feasibility of hybrid laser-GMAW process for welding high strength quenched and tempered steel. Aust. Weld. J. 2012, 57, 1-9.

11. Layus, P.; Kah, P.; Khlusova, E.; Orlov, V. Study of the sensitivity of high-strength cold-resistant shipbuilding steels to thermal cycle of arc welding. Int. J. Mech. Mater. Eng. 2018, 13, 3. [CrossRef]

12. Schaupp, T.; Ernst, W.; Spindler, H.; Kannengiesser, T. Hydrogen-assisted cracking of GMA welded 960 MPa grade high-strength steels. Int. J. Hydrog. Energy 2020, 45, 20080-20093. [CrossRef]

13. Balaguru, V.; Balasubramanian, V.; Shivkumar, P. Tensile properties of shielded metal arc welded ultrahigh hard armour steel joints. World J. Adv. Eng. Tech. Sci. 2020, 1, 71-84. [CrossRef]

14. Xu, X.; Xu, W.; Ederveen, F.H.; van der Zwaag, S. Design of low hardness abrasion resistant steels. Wear 2013, 301, 89-93. [CrossRef]

15. Ojala, N.; Valtonen, K.; Heino, V.; Kallio, M.; Aaltonen, J.; Siitonen, P.; Kuokkala, V.T. Effects of composition and microstructure on the abrasive wear performance of quenched wear resistant steels. Wear 2014, 317, 225-232. [CrossRef]

16. Deng, X.; Wang, Z.; Han, Y.; Zhao, H.; Wang, G. Microstructure and abrasive wear behavior of medium carbon low alloy martensitic abrasion resistant steel. J. Iron Steel Res. Int. 2014, 21, 98-103. [CrossRef]

17. Lindroos, M.; Valtonen, K.; Kemppainen, A.; Laukkanen, A.; Holmberg, K.; Kuokkala, V.T. Wear behavior and work hardening of high strength steels in high stress abrasion. Wear 2015, 322-323, 32-40. [CrossRef]

18. Wang, T.S.; Lu, B.; Zhang, M.; Hou, R.J.; Zhang, F.C. Nanocrystallization and martensite formation in the surface layer of medium-manganese austenitic wear-resistant steel caused by shot peening. Mater. Sci. Eng. A 2007, 458, 249-252. [CrossRef]

19. Bregliozzi, G.; Di Schino, A.; Kenny, J.M.; Haefke, H. The influence of atmospheric humidity and grain size on the friction and wear of AISI 304 austenitic stainless steel. Mater. Lett. 2003, 57, 4505-4508. [CrossRef]

20. Abouei, V.; Saghafian, H.; Kheirandish, S.; Ranjbar, K. An investigation of the wear behaviour of $0.2 \%$ dual phase steels. J. Mater. Process. Technol. 2008, 203, 107-112. [CrossRef]

21. Zum Gahr, K.H. Microstructure and Wear of Materials; Elsevier: Amsterdam, The Netherlands, 1987; 559p. 
22. Wang, X.; Chen, Y.; Wei, S.; Zuo, L.; Mao, F. Effect of carbon content on abrasive impact wear behavior of Cr-Si-Mn low alloy wear resistant cast steels. Front. Mater. 2019, 6, 153. [CrossRef]

23. Kang, Y.J.; Oh, J.C.; Lee, H.C.; Lee, S. Effects of carbon and chromium additions on the wear resistance and surface roughness of cast high-speed steel rolls. Metall. Mater. Trans. A 2001, 32, 2515-2525. [CrossRef]

24. Bhakat, A.K.; Mishra, A.K.; Mishra, N.S. Characterization of wear and metallurgical properties for development of agricultural grade steel suitable in specific soil conditions. Wear 2007, 263, 228-233. [CrossRef]

25. Tang, L.; Gao, C.; Huang, J.; Zhang, H.; Chang, W. Dry sliding friction and wear behaviour of hardened AISI D2 tool steel with different hardness levels. Tribol. Int. 2013, 66, 165-173. [CrossRef]

26. Parashivamurthy, K.I.; Kumar, R.K.; Seetharamu, S.; Chandrasekharaiah, M.N. Review on TiC reinforced steel composites. J. Mater. Sci. 2001, 36, 4519-4530. [CrossRef]

27. Han, Y.; Shi, J.; Xu, L.; Cao, W.Q.; Dong, H. Effects of Ti addition and reheating quenching on grain refinement and mechanical properties in low carbon medium manganese martensitic steel. Mater. Des. 2012, 34, 427-434. [CrossRef]

28. Kostryzhev, A.G.; Killmore, C.R.; Yu, D.; Pereloma, E.V. Martensitic wear resistant steels alloyed with titanium. Wear 2020 446-447, 203203. [CrossRef]

29. Zeatoun, L.A.; Morrison, P.W., Jr. Optimizing diamond growth for an atmospheric oxyacetylene torch. J. Mater. Res. 1997, 12, 1237-1252. [CrossRef]

30. Cutting Processes-Application of Oxyfuel Cutting. Available online: https://www.twi-global.com/technical-knowledge/jobknowledge/cutting-processes-application-of-oxyfuel-cutting-050 (accessed on 20 December 2019).

31. Eyres, D.J. Welding and cutting processes used in shipbuilding. In Ship Construction; Eyres, D.J., Ed.; Butterworth-Heinemann: Oxford, UK, 2007; pp. 75-96.

32. Cutting Processes-Plasma Arc Cutting_Process and Equipment Considerations. Available online: https://www.twi-global com/technical-knowledge/job-knowledge/cutting-processes-plasma-arc-cutting-process-and-equipment-considerations-051 (accessed on 20 December 2019).

33. Wẹlowski, M.S.; Dymek, S.; Kopyściański, M.; Niagaj, J.; Rykała, J.; De Waele, W.; Hertelé, S. A comprehensive study on the microstructure and mechanical properties of arc girth welded joints of spiral welded high strength API X70 steel pipe. Arch. Civ. Mech. Eng. 2020, 20, 14. [CrossRef]

34. Shi, L.; Alexandratos, S.A.; O'Dowd, N.P. Combined finite element and phase field method for simulation of austenite grain growth in the heat-affected zone of a martensitic steel weld. Proc. Inst. Mech. Eng. Part L J. Mater. Des. Appl. 2019, 233, 13-27. [CrossRef]

35. Garcin, T.; Militzer, M.; Poole, W.J.; Collins, L. Microstructure model for the heat-affected zone of X80 linepipe steel. Mater. Sci. Technol. 2016, 32, 708-721. [CrossRef]

36. El-Faramawy, H.S.; Ghali, S.N.; Eissa, M.M. Effect of titanium addition on behavior of medium carbon steel. J. Miner. Mater. Charact. Eng. 2012, 11, 108-1112. [CrossRef]

37. Strid, J.; Easterling, K.E. On the chemistry and stability of complex carbides and nitrides in microalloyed steels. Acta Metall. 1985 33, 2057-2074. [CrossRef]

38. Dobrzanski, L.A.; Zarychta, A.; Ligarski, M. High-speed steels with addition of niobium or titanium. J. Mater. Process. Tech. 1997, 63, 531-541. [CrossRef]

39. Soto, R.; Saikaly, W.; Bano, X.; Issartel, C.; Rigaut, G.; Charai, A. Statistical and theoretical analysis of precipitates in dual-phase steels microalloyed with titanium and their effect on mechanical properties. Acta Mater. 1999, 47, 3475-3481. [CrossRef]

40. Yu, W.T.; Li, J.; Shi, C.B.; Zhu, Q.T. Effect of titanium on the microstructure and mechanical properties of high-carbon martensitic stainless steel 8Cr13MoV. Metals 2016, 6, 193. [CrossRef]

41. Bhadeshia, H.K.D.H.; Honeycombe, S.R. Steels: Microstructure and Properties, 3rd ed.; Butterworth-Heinemann: Oxford, UK, 2006; pp. 183-208.

42. Krauss, G. Tempering of lath martensite in low and medium carbon steels: Assessment and challenges. Steel Res. Int. 2017, 88, 1700038. [CrossRef]

43. Pawłowski, B. Critical points of hypoeutectoid steel—Prediction of the pearlite dissolution finish temperature Ac1f. J. Achiev. Mater. Manuf. Eng. 2011, 49, 331-337.

44. Trzaska, J.; Dobrzanski, L.A. Modelling of CCT diagrams for engineering and constructional steels. J. Mater. Process. Technol. 2007, 192-193, 504-510. [CrossRef]

45. Lu, Q.; Xu, W.; van der Zwaag, S. Designing new corrosion resistant ferritic heat resistant steel based on optimal solid solution strengthening and minimisation of undesirable microstructural components. Comp. Mater. Sci. 2014, 84, 198-205. [CrossRef]

46. Kong, J.; Xie, C. Effect of molybdenum on continuous cooling bainite transformation of low-carbon microalloyed steel. Mater. Des. 2006, 27, 1169-1173. [CrossRef]

47. Hu, H.; Xu, G.; Zhou, M.; Yuan, Q. Effect of Mo content on microstructure and property of low-carbon bainitic steels. Metals 2016, 6, 173. [CrossRef]

48. Mukherjee, S.; Timokhina, I.; Zhu, C.; Ringer, S.P.; Hodgson, P.D. Clustering and precipitation processes in a ferritic titaniummolybdenum microalloyed steel. J. Alloys Compd. 2017, 690, 621-632. [CrossRef]

49. Dhara, S.; Marceau, R.K.W.; Wood, K.; Dorin, T.; Timokhina, I.B.; Hodgson, P.D. Precipitation and clustering in a Ti-Mo steel investigated using atom probe tomography and small-angle neutron scattering. Mater. Sci Eng. A 2018, 718, 74-86. [CrossRef] 
50. Chen, C.Y.; Yang, J.R.; Chen, C.C.; Chen, S.F. Microstructural characterization and strengthening behavior of nanometer sized carbides in Ti-Mo microalloyed steels during continuous cooling process. Mater. Charact. 2016, 114, 18-29. [CrossRef]

51. Kostryzhev, A.G.; Marenych, O.O. New technology to produce 1 GPa low carbon microalloyed steels from cast strip. Metals 2018, 8, 662. [CrossRef]

52. Zhang, K.; Li, Z.D.; Sun, X.J.; Yong, Q.L.; Yang, J.W.; Li, Y.M.; Zhao, P.L. Development of Ti-V-Mo complex microalloyed hot-rolled 900MPa grade high strength steel. Acta Metall. Sin. 2015, 28, 641-648. [CrossRef]

53. Wang, Z.; Zhang, H.; Guo, C.; Liu, W.; Yang, Z.; Sun, X.; Zhang, Z.; Jiang, F. Effect of molybdenum addition on the precipitation of carbides in the austenite matrix of titanium micro-alloyed steels. J. Mater. Sci. 2016, 51, 4996-5007. [CrossRef]

54. Tingaev, A.K.; Gubaydulin, R.G.; Ilin, I.A. Study of the effect of thermal cutting on the microstructure and chemical composition of the edges of workpieces made of steel brands S345, S390. Procedia Eng. 2016, 150, 1783-1790. [CrossRef]

55. Ilin, I.A.; Krasnoperova, A.A.; Sirotkin, E.A. Effect study of thermal cutting methods on the edge's microstructure of high-strength steel grade S700MC. Mater. Sci. Forum 2019, 946, 928-933. [CrossRef]

56. Pawar, S.S.; Inamdar, K.H. Analysis of heat affected zone in plasma arc cutting of SS 316L plates. Int. J. Innov. Res. Sci. Eng. Technol. 2017, 6, 8160-8165.

57. Gustafson, A. Coarsening of TiC in austenitic stainless steel-Experiments and simulations in comparison. Mater. Sci Eng. A. 2000, 287, 52-58. [CrossRef]

58. Jones, A.R.; Ralph, B. Growth and dissolution of NbC particles in an austenitic stainless steel. Metallography 1977, 10, 469-480. [CrossRef]

59. Gong, P.; Palmiere, E.J.; Rainforth, W.M. Dissolution and precipitation behaviour in steels microalloyed with niobium during thermomechanical processing. Acta Mater. 2015, 97, 392-403. [CrossRef]

60. Morral, J.E.; Purdy, G.R. Particle coarsening in binary and multicomponent alloys. Scr. Metall. Mater. 1994, 30, 905-908. [CrossRef]

61. Papaefthymiou, S.; Bouzouni, M.; Gavalas, E. Theoretical study of particle dissolution during homogenization in Cu-Fe-P alloy. Metals 2018, 8, 455. [CrossRef]

62. Abe, F.; Murata, M.; Miyazaki, H. Effect of TiC and NbC carbides on creep life of stainless steels. Mater. High Temp. 2019, 36, 35-47. [CrossRef] 